\title{
The Physiological Relationship of Endothelial Protein Kinase G with Endothelial Nitric Oxide Synthase
}

\author{
Theresa A. John ${ }^{1}$ and J. Usha Raj ${ }^{2}$ \\ ${ }^{1}$ Department of Pharmacology, Lagos State University College of Medicine, Lagos, \\ 2Department of Pediatrics, College of Medicine of the University of Illinois at Chicago, \\ Chicago, Illinois, \\ ${ }^{1}$ Nigeria \\ ${ }^{2}$ USA
}

\section{Introduction}

Furchgott and his co-workers reported the vascular actions of an unknown biological mediator that was named endothelium-derived relaxing factor (EDRF). ${ }^{1}$ Nitric oxide (NO) was soon discovered as a vasodilator that had identical properties with EDRF.2,3,4 NO produced by the endothelium diffuses to the adjacent vascular smooth muscle cells causing them to relax. This function is important in many vascular beds such as the coronary circulation. 5,6

Nitric oxide synthases produce nitric oxide. In the endothelium, constitutive endothelial nitric oxide synthase (eNOS) produces nitric oxide (NO) under normal conditions and in response to chemical and physical stimuli such as shear stress. 6, 7, 8, 9 NO produced from endothelial cells or from platelets serves protective functions such as inhibiting platelet aggregation and adhesion and inhibiting leukocyte adhesion. ${ }^{10,11}$ Nitric oxide produced by constitutive neuronal nitric oxide synthase (nNOS) is a neuromediator in the central nervous system $^{12,13}$ and in peripheral non adrenergic-non cholinergic nerves ${ }^{14,15,16}$ where is mediates many physiological functions.

The second messenger or "molecular receptor" activated by NO to mediate these physiologic functions is soluble guanylate cyclase (GC).17, 18 In the vasculature, this pathway has been clearly outlined to involve intracellular increase in the concentration of cyclic guanosine monophosphate (cGMP),19, 20 activation of protein kinase G (PKG, cyclic GMPdependent protein kinase), ${ }^{21}$ and modulation of activities of cyclic nucleotide phosphodiesterases (PDE, 2, 3, and 5). In vascular smooth muscle cells the net effect is decreased phosphorylation of the myosin light chain, reduction of cytosolic $\mathrm{Ca}^{2+}$ and relaxation of smooth muscle cells. PKG plays a key role in vasodilation. PKG catalyzes the phosphorylation of certain proteins. It also activates myosin light chain phosphatase ${ }^{22}$ causing dephosphorylation of mysosin light chain and vasorelaxation.

A third isoform of the enzyme is inducible nitric oxide synthase (iNOS) which is induced by immunologic stimuli and activated in pathologic conditions. It produces cytotoxic amounts 
of NO for host defense. 23, 24, 25, 26 All three terms: endothelial, neuronal, and inducible are traditional and presently exceptions have been identified in the variety of NOS enzymes.

Many cardiovascular diseases and pathologic conditions are related to abnormalities and irregularities of the NOS function and NO signaling. For example nNOS overproduction of $\mathrm{NO}$ is involved in some forms of epilepsy and iNOS overproduction of NO causes septic shock. Chronic diseases linked to deranged NO production include atherosclerosis, hypertension, cerebral and coronary vasospasm, and erectile dysfunction. Therefore, NO delivery and NO control are therapeutic targets. $27,28,29$ Inhaled NO is especially useful for neonates with persistent pulmonary hypertension. ${ }^{30,31}$ Nitric oxide donors are drugs used to enhance or substitute NO availability. They include organic nitrates and nitrites and have been used to lower blood pressure and for ischemic heart disease. Control of endogenous production of NO is dependent on our knowledge of the enzyme, NOS, that produces NO. Many chemicals have been used to compete with the amino acid L-arginine substrate from which NOS synthesizes NO. Some are experimental tools used to study NOS function, e.g. asymmetric dimethyl-l-arginine. NOS inhibitors may be useful in septic shock and neurodegenerative diseases. ${ }^{6}$ However, we know very little about the life cycle of the enzyme nitric oxide synthase and how it is physiologically regulated: synthesized, deactivated, recycled or replenished in basal conditions in normal endothelial cells. Our recent findings of the relationship between protein kinase $G$ and endothelial nitric oxide synthase open new thoughts on the regulation of nitric oxide synthase. These findings are discussed in this chapter.

\section{Protein kinase $G$ isoforms and their distribution in endothelial cells}

Protein kinase G (PKG) is a serine/threonine-specific protein kinase. It is found in vascular smooth muscle cells (SMCs) and there it mediates the effect of endothelial NO on vascular SMCs to cause relaxation. Recently, we showed the abundance of PKG in quiescent ovine neonatal lung microvascular endothelial cells (LMVECs) and investigations were carried out to find out if $\mathrm{NO}$ within endothelial cells mediates any physiological function through endothelial PKG. A feed-back role of endothelial PKG on activated endothelial NOS appears to be a physiologic regulation of NO production.

PKG is likely to have an important physiologic role in endothelial cells because PKG isoforms are present in normal endothelial cells in distinct patterns of distribution (Figure 1). ${ }^{32}$

\section{Physical intracellular relationship of NOS and PKG: Colocalization of PKG 1 beta and serine-116-phosphorylated endothelial nitric oxide synthase}

Recently, using specific epitope fluorescent immunolabeling of monolayers and confocal microscopy, NOS was shown to colocalize with PKG in neonatal ovine LMVECs. ${ }^{32}$ The confocal imaging of colocalized serine-116-phosphorylated NOS with PKG 1 beta in quiescent MVECs indicated a spatial relationship between the two molecules in intracellular domains (Figure 2). Thus we suspect a role for PKG (1 beta) in normal NOS metabolism in endothelial cells.

Till present, the importance of PKG in endothelial NO signaling has been focused on smooth muscle cell PKG. NO produced by the endothelium freely diffuses across biological 

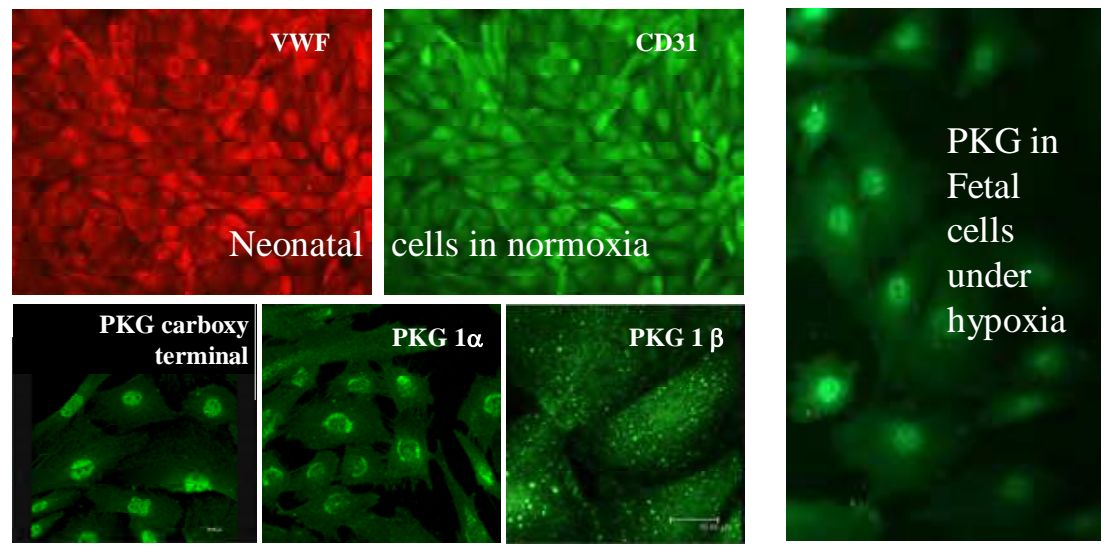

Fig. 1. Fluorescence immunohistochemistry expression of characteristic endothelial markers and some protein kinase $\mathrm{G}$ (PKG) isoforms in primary cultures of lamb lung microvascular endothelial cells (LMVECs). The figure shows newborn lamb (all left panels) and term fetal cells (right panel). The upper left panels show $100 \%$ of cells in the monolayer stained for both von Willebrand Factor (vWF; red alexa 568 staining) and cluster differentiating type antigen 31 (CD31, green alexa 488 staining), characterizing them as endothelial cells. The lower left panels show alexa 488-conjugated secondary antibodies attached to respective primary antibodies. The PKG carboxy terminal is expressed in the cytosol and more intensely in the perinuclear region of LMVEC; PKG $1 \alpha$ staining is localized to the Golgi and endoplasmic reticulum regions of the cells; and PKG $1 \beta$ staining is localized to vesicular structures distributed all over the cell.

membranes and stimulates soluble guanylate cyclase in smooth muscle cells leading to increased intracellular cGMP, activation of PKG, and smooth muscle cell relaxation. The rest of the evidence in this chapter presents an emerging role of an equivalent NO-cyclic GMPPKG signaling pathway in the endothelial cell that appears to produce a negative regulation of NOS (possibly in addition to endothelial relaxation).

\section{Effects of protein kinase $G$ modulator drugs on endothelial intracellular nitric oxide production}

Basal levels of NO production have been difficult to determine because NO has a very short half-life of $5 \mathrm{~s}$ and stimulated NO release is only about $500 \pm 20 \mathrm{nmol} / \mathrm{s}^{33}$ Many previous studies have measured stimulated NO production using agonists such as carbachol and calcium ionophore and these investigations studied factors altering such NOS function. The experimental tool, diaminofluorescein with a difluoro modification (DAF-FM) forms a relatively photo-stable, water soluble adduct, a fluorescent benzotriazole, with $\mathrm{NO}^{34}$ at concentrations as low as $3 \mathrm{nM}$ and can trap $\mathrm{NO}$ as it is produced. Importantly, low doses of DAF can pick up minute differences between groups with minimal diaminofluorescein (DAF) autofluorescence. ${ }^{35}$, 36 The more important novelty about DAF is probably the opportunity it affords us to measure and monitor basal $\mathrm{NO}$ as it is produced by living cells. DAF is thus an interesting tool for studying basal NOS function 37 which we need to understand in order to better regulate nitric oxide production therapeutically. We detected 


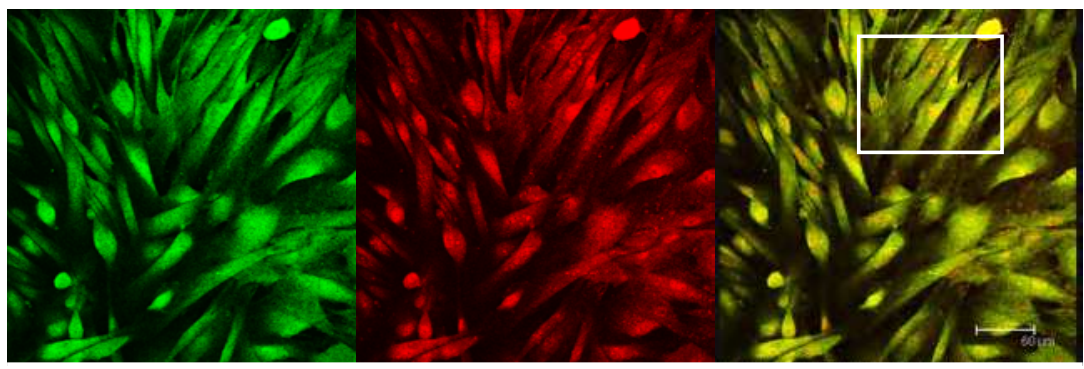

PKG 1 $\beta$-ALEXA 488 AND PSER116-NOS-3-CY3 IN NORMAL EC

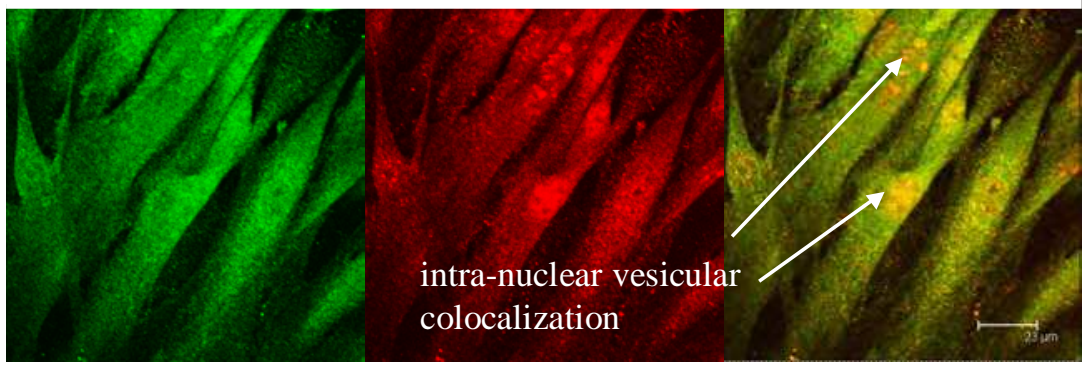

Fig. 2. PKG1beta and serine-116-phosphorylated NOS moieties colocalize in the cytosol and nuclear region vesicles. Quadruplet monolayers of untreated passage 3 neonatal ovine lung microvascular endothelial cells were fixed with $4 \%$ paraformaldehyde, permeabilized with $0.2 \%$ triton $\mathrm{X}-100$, blocked with $20 \%$ bovine serum albumin and then incubated with 1: 200 dilutions of goat anti PKG 1beta and rabbit anti serine116-phosphorylated NOS primary antibodies for $2 \mathrm{~h}$ at room temperature. They were counterstained with 1: 125 dilutions of alexa 488-conjugated donkey anti goat and cy-3 conjugated $\mathrm{F}(\mathrm{ab}) 2$ fragment specific sheep anti-rabbit secondary antibodies. Pictures were taken with a Leica DMIRE2 confocal inverted microscope and Leica v2.61 confocal software. The PKG 1beta and pSer116-NOS markers colocalized in the cytosol and intensely in vesicles in the nuclear region.

nitric oxide produced by isolated LMVECs under basal conditions by DAF fluorescence and it was inhibited by general NOS inhibitors NG-nitro-L-arginine (L-NNA) or N-nitro-Larginine methyl ester (L-NAME). Here we summarize a number of published experiments that show that PKG activation negatively regulates activated NOS. $32,38,39,40,41$

Effects of PKG activation on real time basal and stimulated NO production are shown in Figure 3 and a dose dependency of the inhibitory effect of PKG on basal NO production is shown in Figure 4. The inhibitory effect doubled from $20 \mathrm{nM}$ to 2 micromolar 8-bromo cyclic guanosine monophosphate (8-Br-cGMP) in Figure 4 indicating that this inhibitory mechanism is sensitive to low physiological levels of 8-Br-cGMP. The inhibition of NOS activity by 8-Br-cGMP was prevented by the peptide YGRKKRRQRRRPPLRKKKKKH (DT2), a potent PKG inhibitor, indicating that 8-Br-cGMP inhibits NOS through PKG (Figure 
4). To make such observations, it was necessary to first subtract the large proportion of extraneous fluorescence. Basal NO production is at a very low level compared to stimulated production (Figure 3). The expansion of the fluorescence axis by extraneous fluorescence can minimize or obliterate observation of the effect of drugs on basal NOS activity.

NOS activity can be activated by such stimuli as cholinergic receptor agonists, shear stress, bradykinin receptor agonists, and calcium ionophore.42, 43 Previously, factors modulating NOS were studied largely by investigating stimulated NOS activity, NOS activity in vitro and in transfection-modified cells using mainly the citrulline assay. Such activation and the interaction of NOS and its binding partners may be modulated by proteins such as heat shock protein 90 (HSP90), ${ }^{44}$ nitric oxide synthase traffic inducer (NOSTRIN), ${ }^{45}$ and eNOS interacting protein (NOSIP), ${ }^{46}$ as well as kinase action by Akt (protein kinase B, PKB) and PKA (protein kinase A). ${ }^{47}$ Basal endothelial nitric oxide production has been difficult to measure and study with the citrulline assay. The sensitivity and ease of DAF48 is a valuable tool that has enabled us to study more closely this narrow but important margin of biological activity (Figure 3). Possibly, derangement of basal NOS activity rather than alteration of factors involved in potentiated NOS activity may be the underlying factor in some NOS-related vascular diseases because pathology is often a sustained deviation from the basal or balanced state.

The data showing a physiological inhibitory role of PKG on basal NOS activity may be of clinical significance. The importance of this is not clear but it seems that activated endothelial NOS is not turned off until endothelial PKG is activated, thus ensuring a relationship between endothelial $\mathrm{NO}$ generation and corresponding vascular smooth muscle PKG function. In Figure 5 the effects of various PKG activator and inhibitor drugs also show that nitric oxide production in endothelial cells may be negatively regulated by protein kinase G feedback. In Figure 6 and Figure 7, the use of NOS inhibition shows that the protein kinase $G$ effect appears to be specifically on nitric oxide synthase function.

Lack of basal PKG activity produced by the antagonist, guanosine-3', 5'-cyclic monophosphorothionate 8-bromo Rp isomer, increases basal NOS activity and the effect of the cGMP antagonist is inhibited by NOS inhibitor L-NNA (Figure 6). In Figure 6, after the 5 min time point, the effect of the competitive inhibitor of NOS, LNNA becomes equilibrated and the PKG inhibition can be seen to sustain a cumulative active pool of NOS.

In another experiment using an extended time-course of up to $360 \mathrm{~min}$, L-NNA also enhanced the effect of PKG activator 8-Br-cGMP but reversed the effect of another PKG inhibitor Rp-8-Br-PET-cGMPS on NOS function (Figure 7). The graphs obtained had correlation values of $\mathrm{R}^{2}>0.9$ showing a real relationship between fluorescence changes and time of reaction with drugs. The slopes of the graphs all fall within a narrow range of $7.5-$ 8.19 showing lack of variation and indicating parallel shifts. This suggests a molecular relationship between NOS and PKG modulators based on receptor activity.

These results suggest that the effects of PKG are directly on active NOS function. In summary, basal (and activated) NOS activity is regulated by the downstream activation of PKG by NO-stimulated cGMP production in endothelial cells. It appears that when NOS is activated, the NO produced diffuses to the smooth muscle but some of the NO triggers an endothelial PKG sensitive signaling that results in inhibition of the activated NOS within the endothelial cell. 

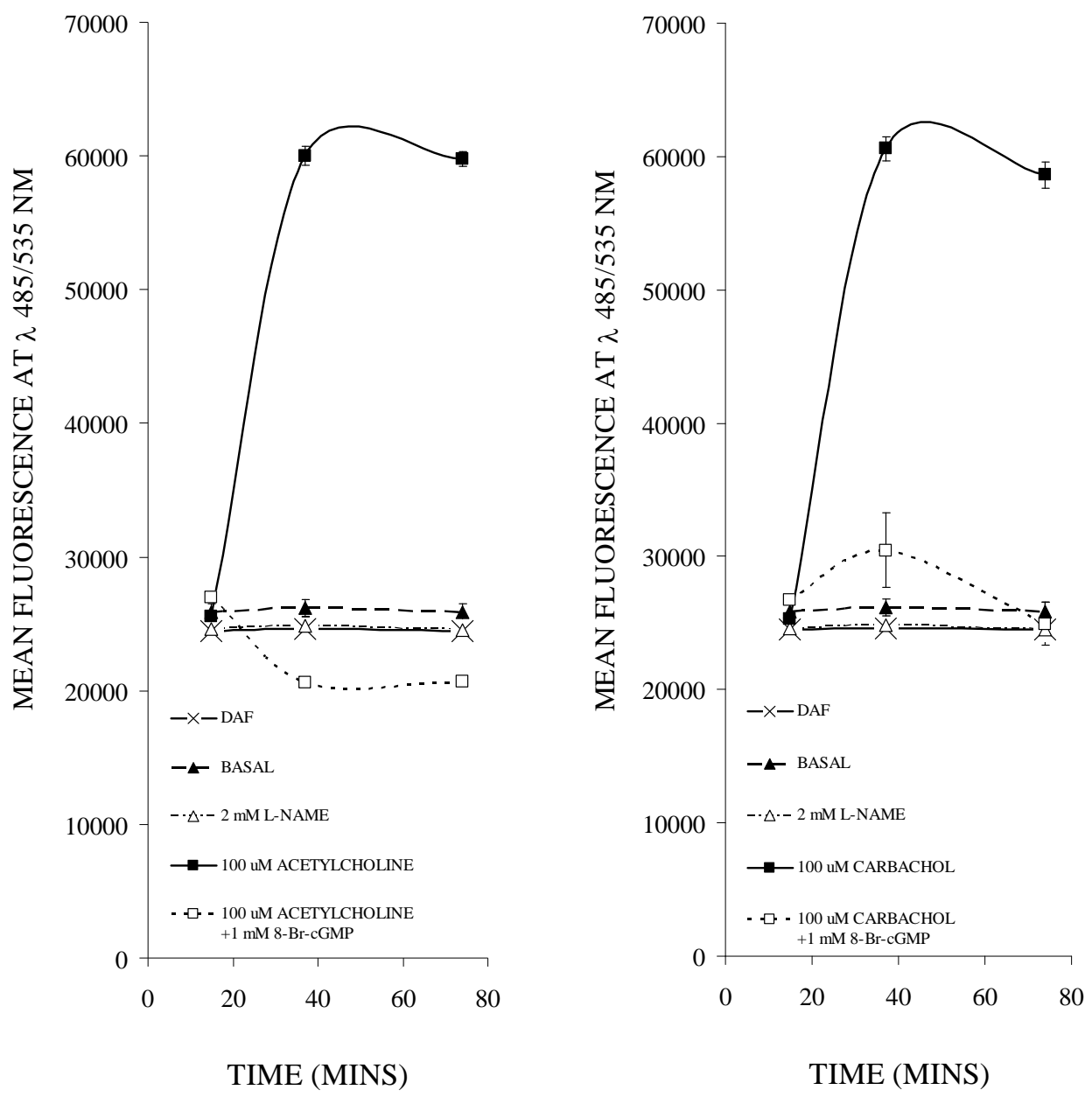

Fig. 3.38 Exogenously administered 8-Br-cGMP attenuates stimulated nitric oxide synthase function in ovine LMVECs. Confluent monolayers of sibling cells of passage 4 were used. A set of 12 wells with no cells was used to measure DAF autofluorescence in the reaction mixture over the time-course of the experiment. To determine the level of extraneous fluorescence in the experimental groups, a group of 12 microcultures were treated with NOS inhibitor $2 \mathrm{mM}$ L-NAME $1 \mathrm{~h}$ before DAF. In all the other groups, drugs (100 microM acetyl choline or 100 microM carbachol followed by $1 \mathrm{mM} 8$-Br-cGMP) were administered just before a mixture of 1 microM DAF FM and 2.4 microM DAF-FM diacetate. The basal NO group received only the fluorophore. Cells were measured at intervals, starting at $15 \mathrm{~min}$ after DAF, for total NO (in intracellular and cell bathing medium) that combined with DAF to produce fluorescence. All graphs shown are from means of raw fluorescence \pm SE of 8 or more microcultures per point from a single experiment. Figure shows a representative of 2 similar experiments. 8-Br-cGMP antagonized the stimulating effects of both acetylcholine and carbachol on nitric oxide production. 

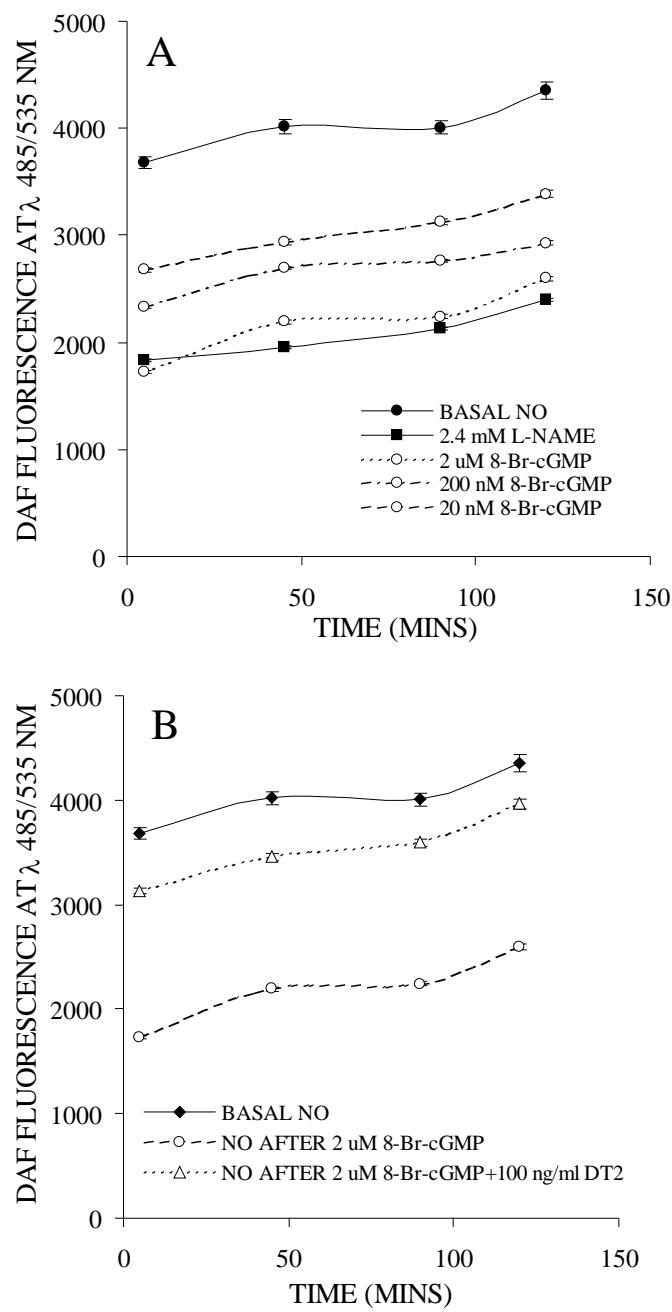

Fig. 4. ${ }^{38}$ Exogenously administered 8-Br-cGMP attenuates basal nitric oxide synthase function in ovine LMVECs. Confluent monolayers of sibling cells of passage 2 were used in 96 well clusters. They were treated with NOS inhibitor $2.4 \mathrm{mM}$ L-NAME to determine the level of extraneous fluorescence in the experimental groups, with $20 \mathrm{nM}-2$ microM 8-BrcGMP to observe its effect on basal nitric oxide production, with PKG inhibitor $100 \mathrm{ng} / \mathrm{ml}$ DT2 to determine if 8-Br-cGMP acts through PKG. DT2 or L-NAME were administered $1 \mathrm{~h}$ before DAF. 8-Br-cGMP was administered 5 min before DAF. A mixture of 0.5 microM DAF FM and 0.8 microM DAF-FM diacetate was used to measure the NO in the cell bathing medium and intracellular NO together. The basal NO group received only the fluorophore. All graphs shown are from means of corrected fluorescence \pm SE of 8 or 12 microcultures per point from a single experiment. Final fluorescence measurements are raw means minus corresponding means of DAF autofluorescence. The figure is a representative of 3 experiments. 

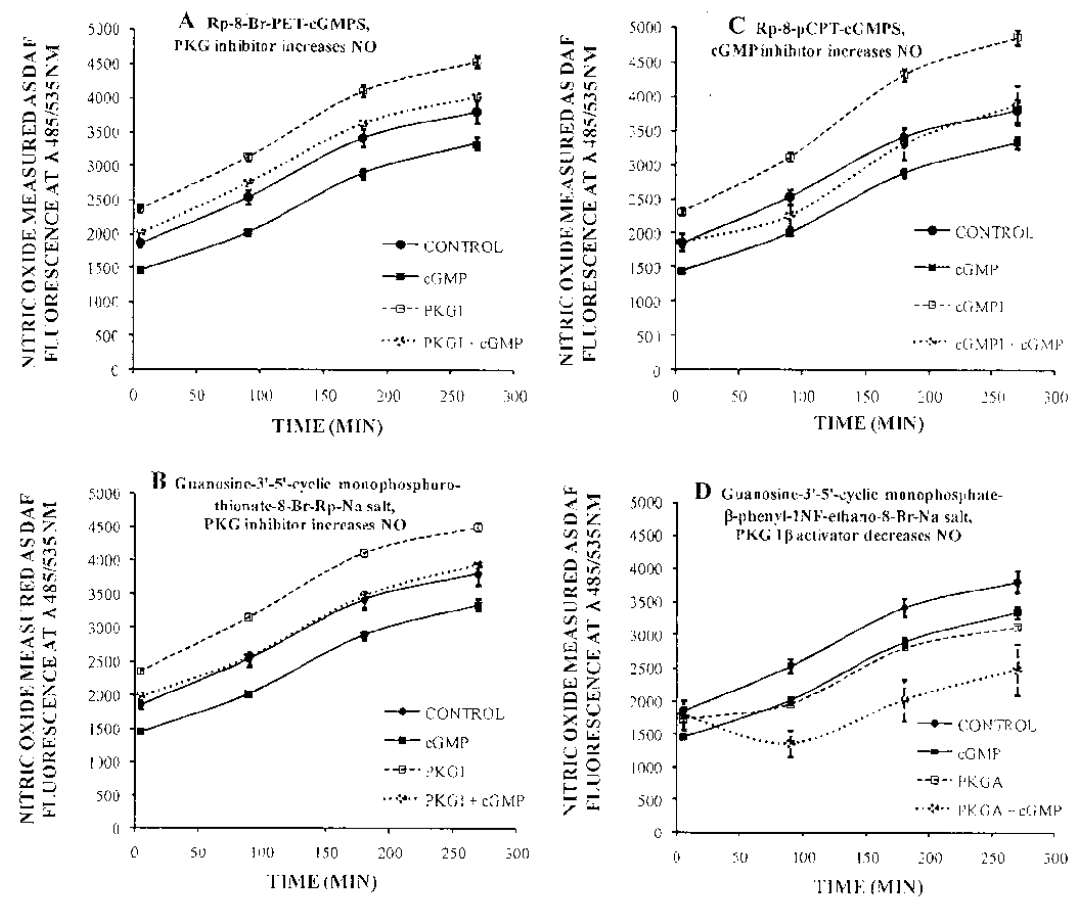

E 90 MINUTESMEASUREMEYIS OHNITRICOXIDE

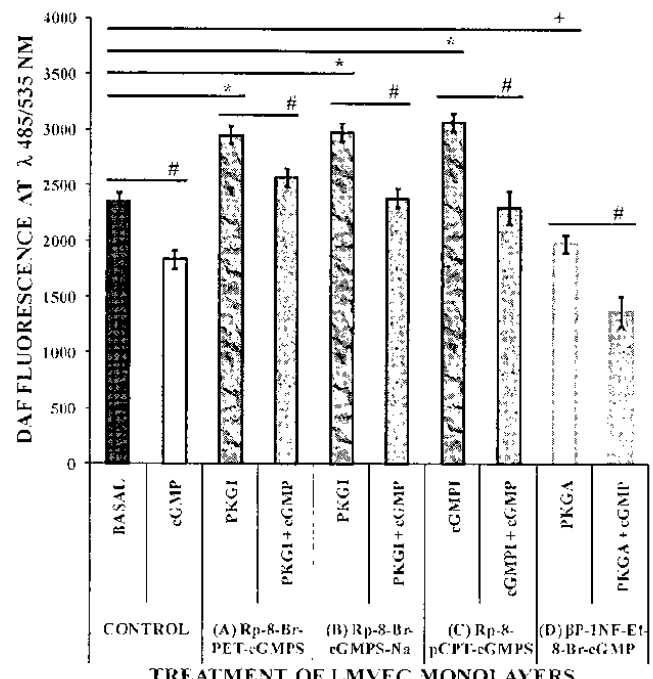

TREATMENT OF LMYEC MONOLAYERS

Fig. 5. ${ }^{39}$ Timecourse of the inhibition of nitric oxide production by protein kinase G: modifications by PKG inhibitor and activator drugs. Nitric oxide measurements were done using 4,5-diamino-fluorescein derivative, DAF-FM, (0.5 $\mu \mathrm{M}$ DAF-FM and 0.8 $\mu \mathrm{M}$ DAF FM 
diacetate) added to stably confluent microcultures of LMVECs in 96-well clusters. To show the basic effect of PKG activation, cells were incubated with $100 \mu \mathrm{M} 8$-Br-cGMP. Other experimental groups were preincubated with a modulator drug: PKG inhibitors $100 \mu \mathrm{M}$ Rp8-Br-PET-cGMPS or $50 \mathrm{nM}$ guanosine 3'-5'-cyclic mono-phosphoro thionate-8-Br-Rp isomer Na salt; cGMP inhibitor: $4 \mu \mathrm{M}$ Rp-8-pCPTcGMPS; or PKG activator: $100 \mu \mathrm{M}$ guanosine-3'-5' cyclic monophosphate- $\beta$-phenyl-1NF-ethano-8-bromo sodium salt. Inhibitors were added 30 min before DAF and activators were added with DAF. Total NO produced after 5, 90, 180 and 270 min of incubation with DAF at $37^{\circ} \mathrm{C}$ was measured using a Victor 1420 multilabel counter (Waltham, Massachusetts) with a fluorescein setting ( $\lambda$ ex/em 485/535 nm). Using the 90 min time point, the data plotted as mean \pm SE show that 8 -Br-cGMP reduces NO production in controls and in all the tests with cGMP/PKG inhibitor drugs as well as in tests with the PKG activator ( $\mathrm{p}<0.05 \#$ in all cases). The cGMP/PKG inhibitor drugs (A), (B) and (C) significantly increased NO production ( $\mathrm{p}<0.05^{*}$ in all cases) and the PKG activator guanosine-3'-5'-cyclic monophosphate- $\beta$-phenyl-1NF-ethano-8-bromo sodium salt (D) significantly decreased NO production $\left(\mathrm{p}^{<0.05+)}\right.$ (lower figure).

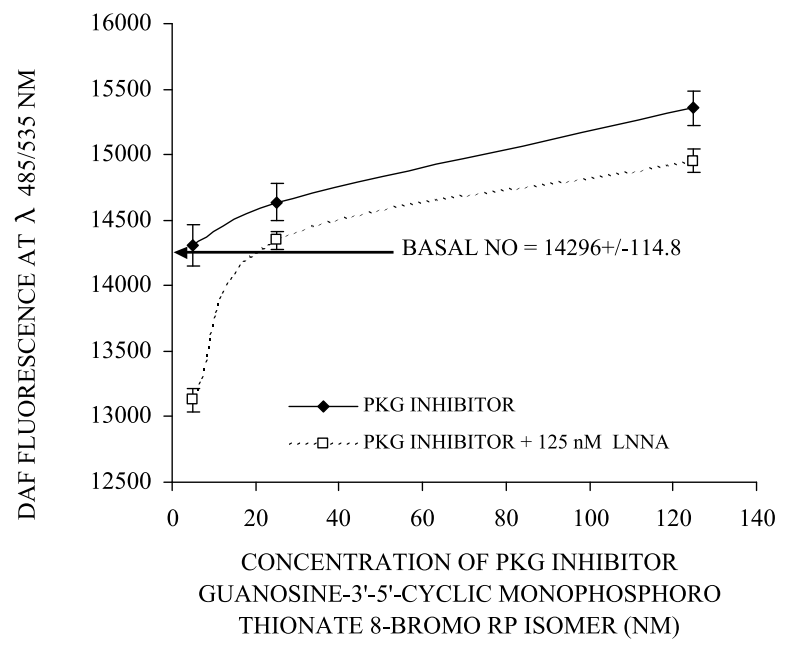

Fig. 6. ${ }^{38}$ Basal nitric oxide production in ovine LMVECs is enhanced by lack of basal endothelial PKG activity and this effect is attenuated by nitric oxide synthase inhibitor LNNA. Confluent monolayers of sibling cells of passage 4 were used in groups of $\mathrm{N}=12$ for basal and $\mathrm{N}=6$ for test groups of microcultures. Cells were treated with different concentrations of cGMP antagonist guanosine-3', 5'-cyclic monophosphorothionate 8-bromo Rp isomer (for PKG inhibition) added 30 min before DAF or with the same concentrations of the cGMP antagonist plus $125 \mathrm{nM}$ L-NNA previously added $2 \mathrm{~h}$ before DAF. A mixture of 0.5 microM DAF FM and 1 microM DAF-FM diacetate was used to measure total intracellular and cell bathing medium NO that combined with DAF to produce fluorescence. Measurements were made $15 \mathrm{~min}$ after DAF was applied. The arrow shows the level of basal $\mathrm{NO}$ at $15 \mathrm{~min}$ in an identical third group not treated with drugs. All graphs shown are from means \pm SE. Figure shows a representative of 2 similar experiments. The PKG inhibition dose-dependently increased NO measured. The inhibition of this effect by L-NNA shows it is through NOS. 

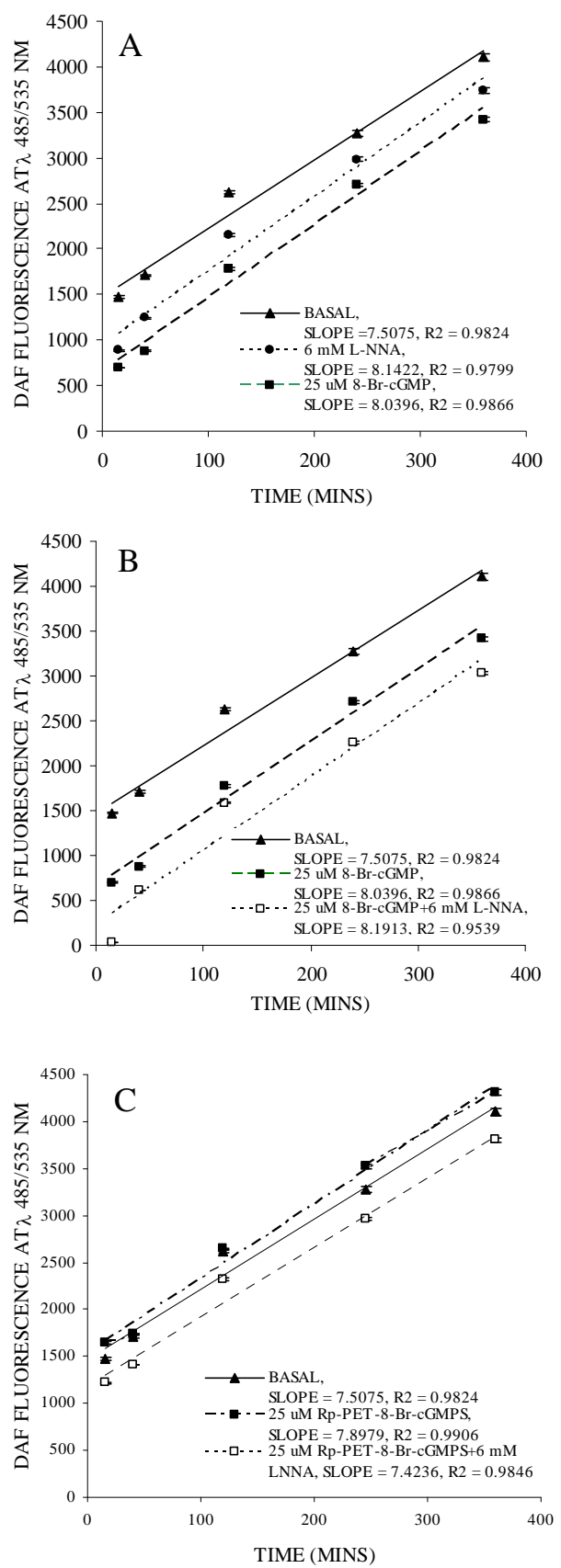

Fig. 7.38 Specificity of PKG effects on NOS function: NOS inhibitor LNNA enhances the effect of PKG activator 8-Br-cGMP on NOS function and reverses the effect of PKG inhibitor 
Rp-8-Br-PET-cGMPS on NOS function. Confluent monolayers of sibling cells of passage 4 were used. Inhibitors, $6 \mathrm{mM}$ L-NNA and 25 microM Rp-8-Br-PET-cGMPS were administered $2 \mathrm{~h}$ and $1 \mathrm{~h}$ respectively before DAF and the PKG activator, 25 microM 8-BrcGMP $<5$ min before DAF. A mixture of 0.5 microM DAF FM and 0.8 microM DAF-FM diacetate was used to measure total intracellular and cell bathing medium NO that combined with DAF to produce fluorescence. All graphs shown are means \pm SE of 12 for basal and 6 for tests microcultures per point. Figure shows a representative of 2 similar experiments. A: Inhibition by L-NNA or 8-Br-cGMP produced a parallel shift of the basal NOS activity graph downwards. B: Synergy of the effects of L-NNA and 8-Br-cGMP coadministered. C: The effect of PKG inhibition produces a parallel shift of basal NOS activity graph upwards and this shift is antagonized by L-NNA.

\section{Relationship of PKG activation and phosphorylation of NOS at various sites}

Constitutive nitric oxide synthase in endothelial cells is localized to caveolae 49 , 50 where it docks into the intracellular domain 4 of the bradykinin B2 receptor. ${ }^{51}$ The structural protein of caveolae, caveolin-1, also binds to NOS keeping it inactive ${ }^{52}$ Activation of NOS leading to its dissociation from the complex is calcium dependent.9, 52 A further activation on serine $1177 / 1179$ is produced by kinase activity. ${ }^{42}$ Several kinases are known to phosphorylate NOS, 53 regulating its activity negatively or positively under experimental conditions. Apart from constitutive caveolin-1, other negative regulators of NOS are NOSIP54 and NOSTRIN. 55 Both interfere with the association of NOS with caveolae and cause its redistribution from the plasma membrane to intercellular compartments with a decrease in nitric oxide (NO) production.

Three positive regulators of NOS have been identified. The protein kinase AKt (PKB) phosphorylates NOS on serine 1177/1179, enhancing NOS activation. ${ }^{56}$ Protein kinase A also phosphorylates NOS to increase its activity. ${ }^{47}$ HSP90 is a molecular scaffold that facilitates the interaction of kinases and substrates including NOS. It facilitates the dissociation of NOS from caveolae in response to calcium-calmodulin. ${ }^{44,}{ }^{57}$ An emerging role of protein kinase $\mathrm{G}$ in NOS regulation is interesting because not only is it a regular downstream component of the physiologic NO signaling pathway that could give feedback regulation, but also because experimentally, its involvement in NOS phosphorylation can be related to its regulation of NOS function. Presently, PKG is unnoticed as a physiological regulator of NOS.58

We recently published fluorescence activated cell sorter (FACS) analysis of the relationship between PKG and endothelial NOS (Figures 8-10). ${ }^{39}$ In summary, 5 microM 8-Br-cGMP in $<5$ min caused an increase in N-terminal labeling of NOS and a decrease in both C-terminal and serine 1177 labeling of NOS. 8-Br-cGMP appeared to increase PKG $1 \alpha$ and to decrease PKG $1 \beta$ labeling. Changes in other phosphorylation sites were less consistent but overall mean channel fluorescence increased from 19.92 to 217.36 for serine 116 and decreased from 329.27 to 254.03 for threonine 495 phosphorylation. Data indicated that PKG caused both molecular and phosphorylation changes in NOS. Thus an implicated role of PKG and serine 116 phosphorylation site on NOS may be a future focus for studying the termination of activated NOS function and the vesicular processing of the spent enzyme. Several evidences from confocal microscopy further develop this. 
untreated LMVEC monolayers in $75 \mathrm{~cm}^{2}$ flasks
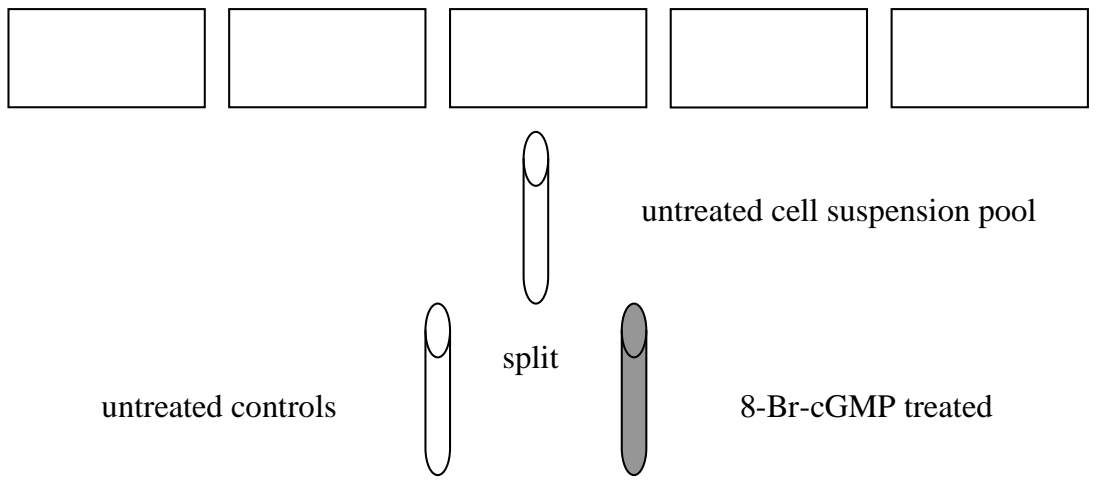

cells fixed, permeabilized, blocked and then split

specific antibody probing per pair of control and 8-Br-cGMP treated cells
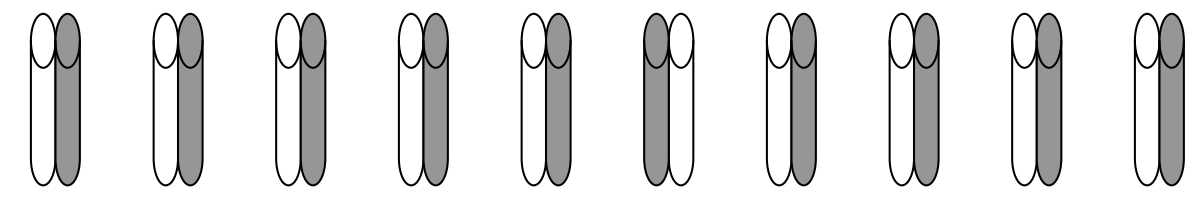

control M-NOS

R-NOS NOS-CT NOS-NT PKG $1 \alpha$ PKG $1 \beta$

pS1177

pS116

pT495

Fig. 8. ${ }^{39}$ Schema of experimental protocol for fluorescence activated cell sorter analysis of the effect of cGMP on antibody labeling of NOS regions and protein kinase G isoforms. Sibling cells were pooled and equally distributed for controls and tests. 
Untreated / Unlabeled FITC

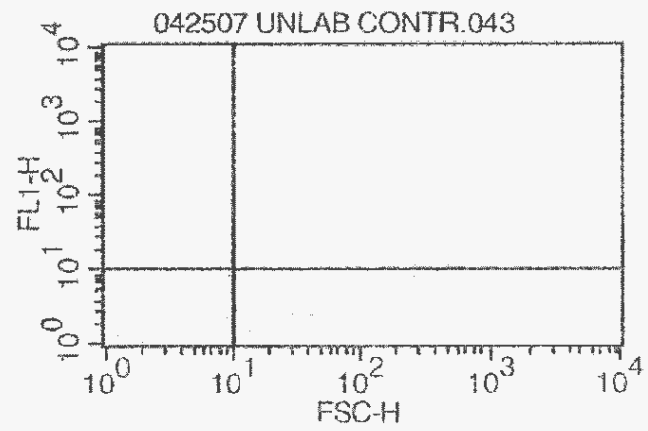

A

B

\begin{tabular}{lrrrrrr} 
FACS ANALYSIS & \multicolumn{2}{c}{ 1ST } & \multicolumn{2}{c}{ 2ND } & \multicolumn{2}{c}{ 3RD } \\
& CONTROL & $8-B r-C G M P$ & CONTROL & 8-Br-CGMP CONTROL & 8-Br-CGMP \\
NOS-NT & 1.78 & 4.71 & 0.25 & 0.52 & 0.07 & 1.43 \\
NOS-CT & 4.42 & 1.84 & 1.41 & 0.92 & 1.15 & 0.85 \\
PS1177-NOS & 2.28 & 1.39 & 2.05 & 0.83 & 0.75 & 0.62 \\
PS116-NOS & 2.32 & 1.86 & 0.36 & 0.41 & 0.22 & 0.5 \\
pT495-NOS & 2.44 & 1.84 & 1.04 & 1.75 & 0.68 & 1.16
\end{tabular}

C

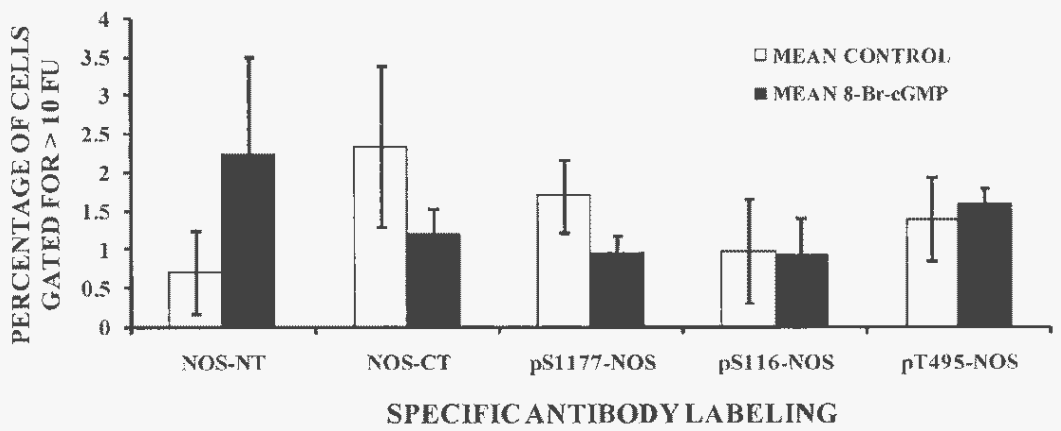

Fig. 9.39 Effect of PKG activation on percentage of cells with high fluorescence intensity for various immunolabeling. Cell suspensions in phosphate buffered saline (PBS) containing 5\% antibiotic/antimycotic mixture were split equally into control and $5 \mu \mathrm{M} 8$-Br-cGMP treatment groups before fixation with $4 \%$ paraformaldehyde. Cell were permeabilized with methanol, blocked with $20 \mathrm{mg} / \mathrm{ml}$ bovine serum albumin (BSA) and then labeled with 1: 100 primary antibodies against NOS N-terminus, NOS C-terminus, or serine 1177 , serine 116, or threonine 495 phosphorylated NOS for $2 \mathrm{~h}$. They were counterlabelled with FITC conjugated secondary antibodies and ran through a BD FACSCallibur. Cells with positive signal of fluorescence were analysed using a FITC (fluorescein) filter (FL1). Upper figure shows gating of cells for 10 fluorescence units (y-axis) and 10 forward scatter units (x-axis). Middle table shows actual Cell Quest read out values for \% gated. The mean values of the three determinations were plotted in the lower figure. 

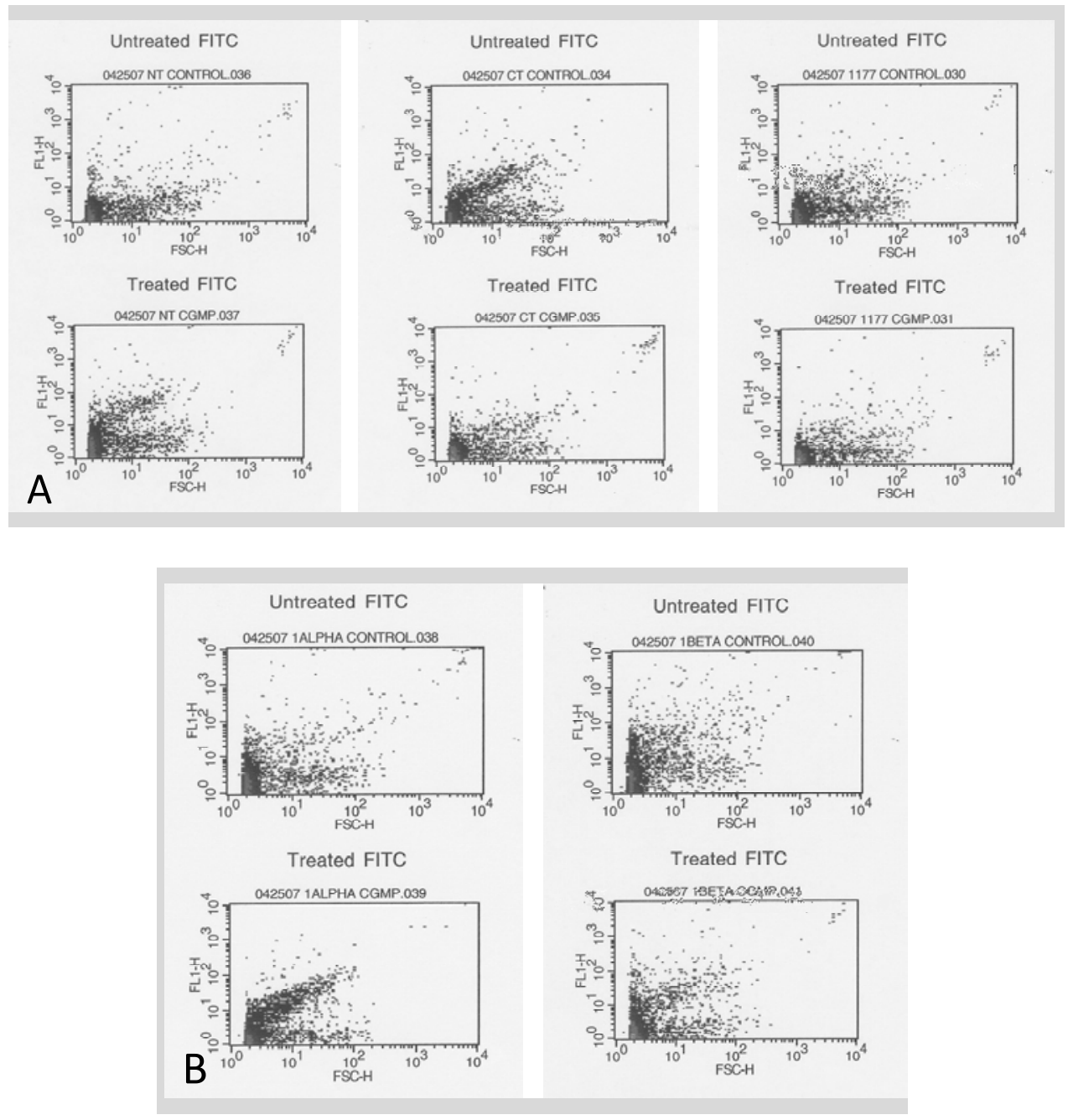

Fig. $10 .{ }^{39}$ A. FACS analysis of the effect of PKG activation on NOS N-terminal and Cterminal specific rabbit antibody labeling and pSer1177 NOS specific antibody labeling. Cells were immunolabeled as described for Figure 9. The fluorescence intensities of sample populations were captured with a Cell Quest software. Upper channels show control cells and lower channels show PKG activator $5 \mu \mathrm{M}$ 8-Br-cGMP treated cells. Left panels were labeled with a rabbit anti N-terminal of NOS antibody. Middle panels were labeled with a rabbit anti C-terminus of NOS antibody. Right panels were labeled with a rabbit anti serine 1177 phosphorylated NOS antibody. The fluorescence intensity range (y-axis) was increased by PKG activation for N-terminal labeling and decreased by PKG activation for C-terminal labeling. The fluorescence intensity range was decreased by PKG activation for serine 1177 phosphorylation. B. FACS analysis of the effect of PKG activation on antibody labeling of protein kinase $\mathrm{G}$ isoforms. Upper channels show control cells and lower channels show PKG 
activator $5 \mu \mathrm{M} 8$-BrcGMP treated cells. Left panels were labeled with a goat anti PKG 1a antibody. Right panels were labeled with a goat anti PKG $1 \beta$ antibody. PKG activation increased total number of cells with $>10^{1}$ fluorescence units (FU) (y-axis) labeling for PKG $1 \alpha$ and decreased the same labeling for PKG $1 \beta$.

\section{PKG phosphorylated nitric oxide synthase in endothelial cells}

The colocalization of serine 116-phosphorylated NOS with PKG suggests that PKG phosphorylates NOS at serine 116 but this has not been directly demonstrated. If this is true, serine 116 phosphorylation of NOS may be connected with the process of terminating the action of NOS after synthesizing NO. The functional data showing modulation of NO production by cGMP and the FACS data showing the effect of cGMP on C- and N-terminal expressions of NOS and phosphorylation expressions of NOS add up to suggest that serine-116 phosphorylated NOS is a spent form of the enzyme. Figure 11 from our published data ${ }^{32,} 41$ indicates that serine116phosphorylated NOS is not like nascent NOS that is known to be associated with the plasmalemma and golgi. Serine 116 phosphorylated NOS is found in the cytosol and in endoplasmic reticulum (ER) and nuclear site vesicles. Figure $12^{41}$ clearly shows that this form of NOS is not associated with the plasma membrane. On the other hand, unphosphorylated NOS colocalizes with caveolin in the plasmalemma and in the Golgi (Figure 13). ${ }^{41}$

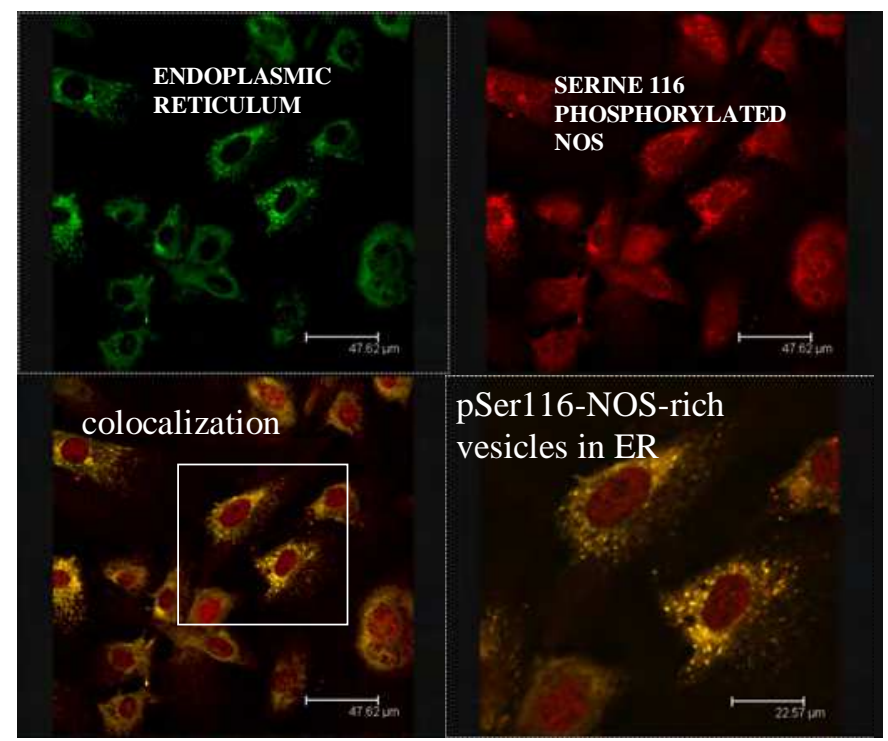

Fig. 11. Serine 116-phosphorylated NOS is found in vesicular structures in endothelial cell endoplasmic reticulum and nuclear regions. Triple monolayers of untreated passage 3 neonatal ovine lung microvascular endothelial cells were fixed with $4 \%$ paraformaldehyde, permeabilized with $0.2 \%$ triton X-100, blocked with $20 \%$ bovine serum albumin and then incubated with mouse anti protein disulfide isomerase (1:200) (an endoplasmic reticulum (ER)-specific marker) and rabbit anti serine116-phosphorylated NOS (1: 200) primary antibodies for $2 \mathrm{~h}$ at room temperature. They were counterstained with 1: 125 dilutions of $\mathrm{F}(\mathrm{ab}) 2$ fragment specific sheep anti mouse conjugated to green fluorescein isothiocyanate 
(FITC) and sheep anti rabbit conjugated to red cy-3 secondary antibodies. Pictures were taken with a DMIRE2 confocal inverted microscope and Leica v2.61 confocal software. Insert shows that a serine 116 phosphorylated NOS moiety passes through the ER and nuclear regions of quiescent cells in certain processing vesicles indicating a NOS metabolic pathway.

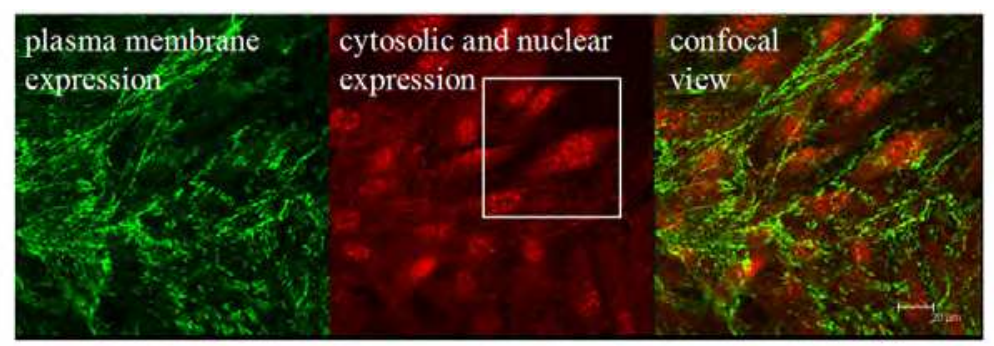

PY14-CAVEOLIN-1-ALEXA 488 AND PSER116-NOS-3-ALEXA 594 IN EC

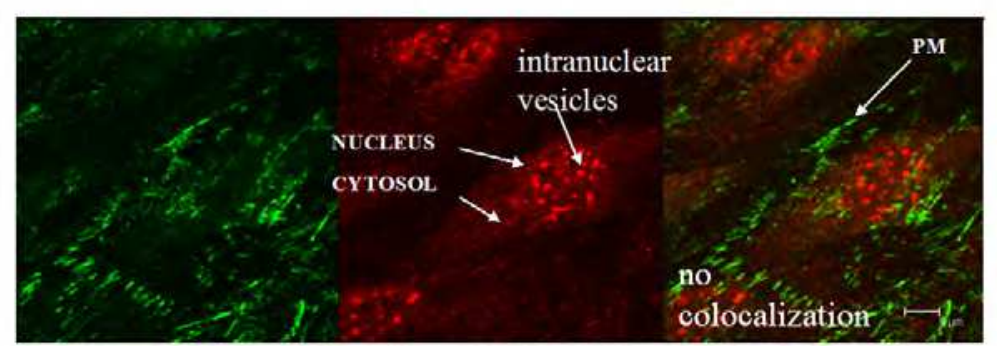

Fig. 12. Plasmalemma associated tyrosine14-phosphorylated caveolin-1 and serine 116phosphorylated NOS are differentially located in endothelial cells. Triple monolayers of untreated passage 2 neonatal ovine lung microvascular endothelial cells were fixed with $4 \%$ paraformaldehyde, permeabilized with $0.2 \%$ triton X-100, blocked with $20 \%$ bovine serum albumin and then incubated with mouse anti tyrosine14-phosphorylated caveolin-1 (1: 200) and rabbit anti serine116-phosphorylated NOS (1: 200) primary antibodies for $2 \mathrm{~h}$ at room temperature. They were counterstained with 1: 125 dilutions of $\mathrm{F}\left(\mathrm{ab}^{\prime}\right) 2$ fragment specific goat secondary antibodies against mouse conjugated to green alexa 488 and against rabbit conjugated to red alexa 594. Pictures of a field representative of all three monolayers are shown taken with a DMIRE2 confocal inverted microscope and Leica v2.61 confocal software. Upper panel shows separation of pY14-caveolin-1 marker distinctively in plasma membrane and pSer116-NOS marker distinctively in the cytosol and nuclear region. Insert from upper panel shown in lower panel depicts the intense distribution of the pSer116-NOS moiety in nuclear region vesicles.

Caveolin-1 is a regulator of NOS that has been well studied. From published work, immunoprecipitation of NOS from bovine lung microvascular endothelial cells resulted in co-precipitation of caveolin- $1 .{ }^{49}$ Caveolin- 1 is well known to be abundant in the membrane region. 59,60 The binding of caveolin-1 to NOS has been shown to negatively regulate NOS activity. ${ }^{51,52}$ NOS is bound to caveolin- 1 before being activated by extracellular signals and PKG does not appear to be involved in such inhibition of NOS at the plasma membrane. In the evidence presented here, PKG activation decreases the immunodetection of serine 1177 phosphorylated moiety of NOS showing that it may be involved in deactivation of activated NOS (Figure 14). 


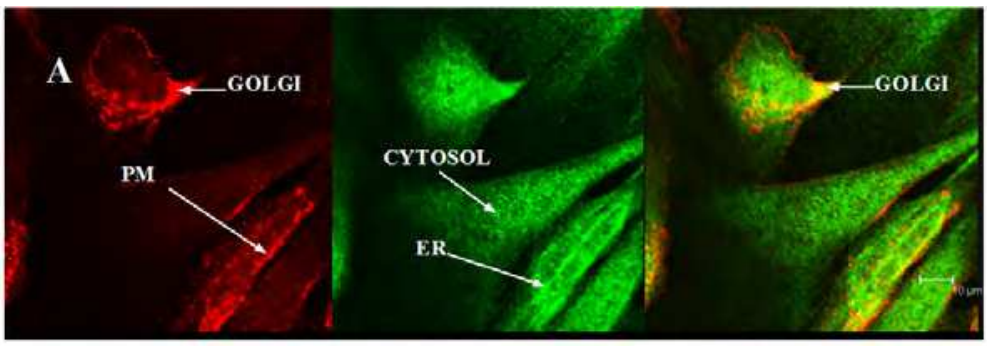

CAVEOLIN-1-ALEXA 594 AND NOS-3-ALEXA 488 IN NORMAL EC
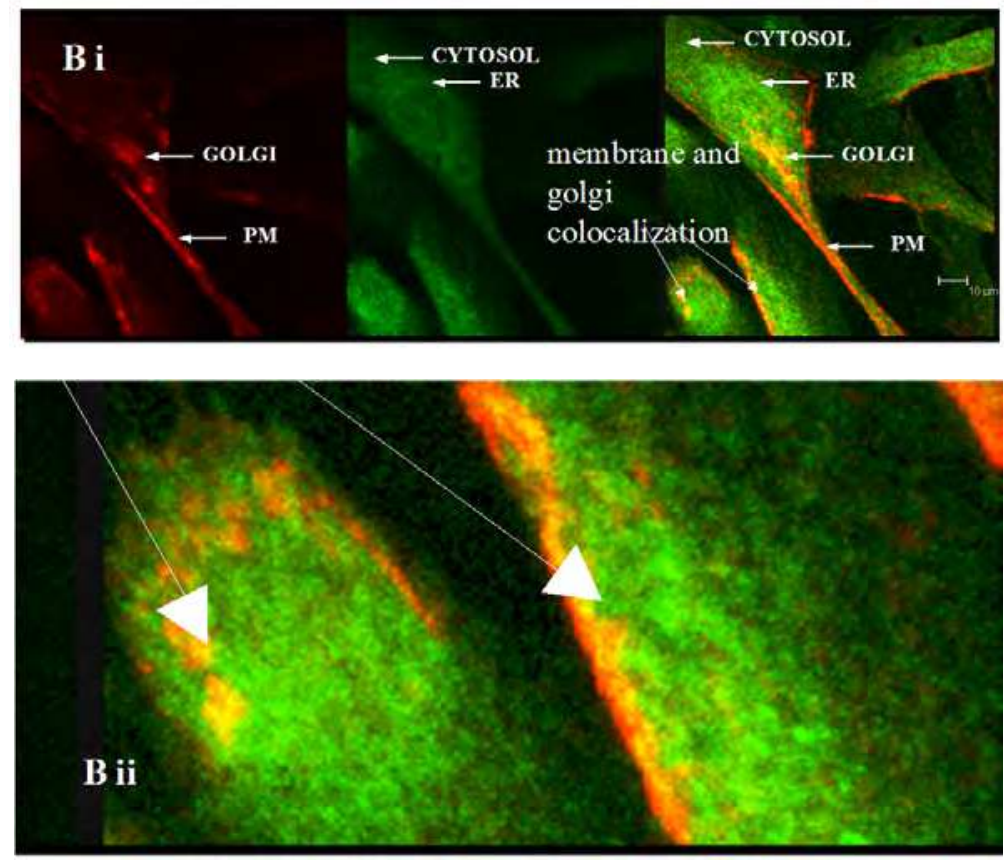

MEMBRANE AND GOLGI COLOCALIZATION OF CAVEOLIN-1 AND NOS

Fig. 13. Caveolin-1 and endothelial NOS (NOS-3) colocalize in the plasmalemma and Golgi in untreated endothelial cells. Triple monolayers of passage 2 neonatal ovine lung microvascular endothelial cells were fixed with $4 \%$ paraformaldehyde, permeabilized with $0.2 \%$ triton X-100, blocked with $20 \%$ bovine serum albumin and then incubated with affinity purified rabbit anti caveolin-1 (1: 200) and monoclonal anti NOS(1: 200) primary antibodies overnight at $4 \mathrm{C}$. They were counterstained with $1: 125$ dilutions of $\mathrm{F}\left(\mathrm{ab}^{\prime}\right) 2$ fragment specific goat secondary antibodies against rabbit conjugated to red alexa 594 and against mouse conjugated to green alexa 488. Pictures were taken with a DMIRE2 confocal inverted microscope and Leica v2.61 confocal software. Arrows show areas of caveolin-1 and NOS co-localization seen in random fields from two monolayers (A and B i) with en-largement of some membrane portion of $B$ to show numerous minute membranous colocalization foci (yellow, B ii) (scale shows 10 micro meters). 


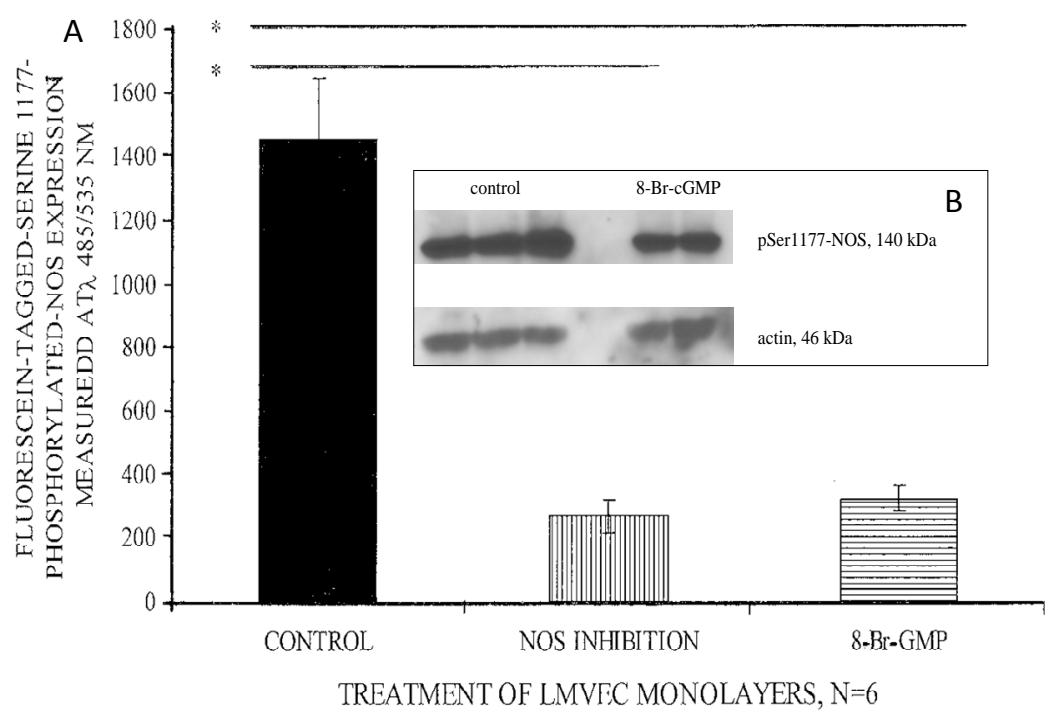

Fig. 14. ${ }^{39}$ A: PKG activation decreases pSer1177-NOS immunofluorescence. To quantitatively determine the effect of PKG activation on pSer1177-NOS expression, stably confluent monolayers of LMVECs grown in 96-well clusters were treated with NOS inhibitor $1 \mathrm{mM} \mathrm{L-}$ NNA $1 \mathrm{~h}$ before or PKG activator $20 \mu \mathrm{M}$ 8-Br-cGMP (Calbiochem, CA) $10 \mathrm{~min}$ before fixation. Monolayers fixed with $4 \%$ paraformaldehyde were permeabilized with $0.2 \%$ triton X-100 in PBS for 2 min, blocked with Chemicon ${ }^{\circledR}$ blocking reagent by 30 min incubation, and then incubated with rabbit anti-pSer1177-NOS primary antibody (Santa Cruz) overnight at $4 \mathrm{C}$. The cells were counter-labeled with an antirabbit fluorescein (FITC)-tagged secondary antibody (Sigma, MO). The fluorescence was read with a Victor 1420 multilabel counter with a fluorescein setting ( $\lambda$ ex/em 485/535 nm). Both L-NNA and 8-Br-cGMP significantly* decreased fluorescence produced by the presence of fluorescein-tagged serine 1177 phosphorylation of NOS ( $<<0.01$ in both). Figure is a representative of two studies. Insert, B, shows similar results of cGMP decreasing serine 1177 phosphorylated NOS expression in western blots.

The process of regulation of NOS after production of nitric oxide is not yet delineated $61,62,63$, , 42 and may be governed by subcellular translocation involving the Golgi network. ${ }^{64,65,66,67}$ The nucleus has not been considered as playing a prominent role in the metabolism of NOS. We localized serine-116- phosphorylated NOS (pSer116-NOS) in distinct vesicles in the cell nuclei as well as in the endoplasmic reticulum. At both sites, we found pSer116-NOS colocalized with protein kinase G1 $\beta$. Thus, PKG appears to be directly involved in inactivation of NOS after NO production and to be chaperoned with spent NOS.

\section{The implication of increased intracellular serine116-NOS detection after exogenous cGMP administration to cultured cells}

Both in-cell fluorescence and Western blots detections suggest that serine-116phosphorylated NOS is normally found in the endothelial cells and can be increased by 
exogenous cGMP administration (Figures 15 and 16). It appears that there is a basal mechanism of removal of this phosphorylated NOS and administration of excess cGMP overwhelms this mechanism causing an accumulation. The mechanism does not seem to be by destruction of the serine-116 terminal (FACS analysis) but may be by internalization and translocation in subcellular compartments. Vesicles are implicated as the use of filipin, which disrupts lipid membranes, disturbed the effects of cGMP on NOS (Figure 17). ${ }^{32}$
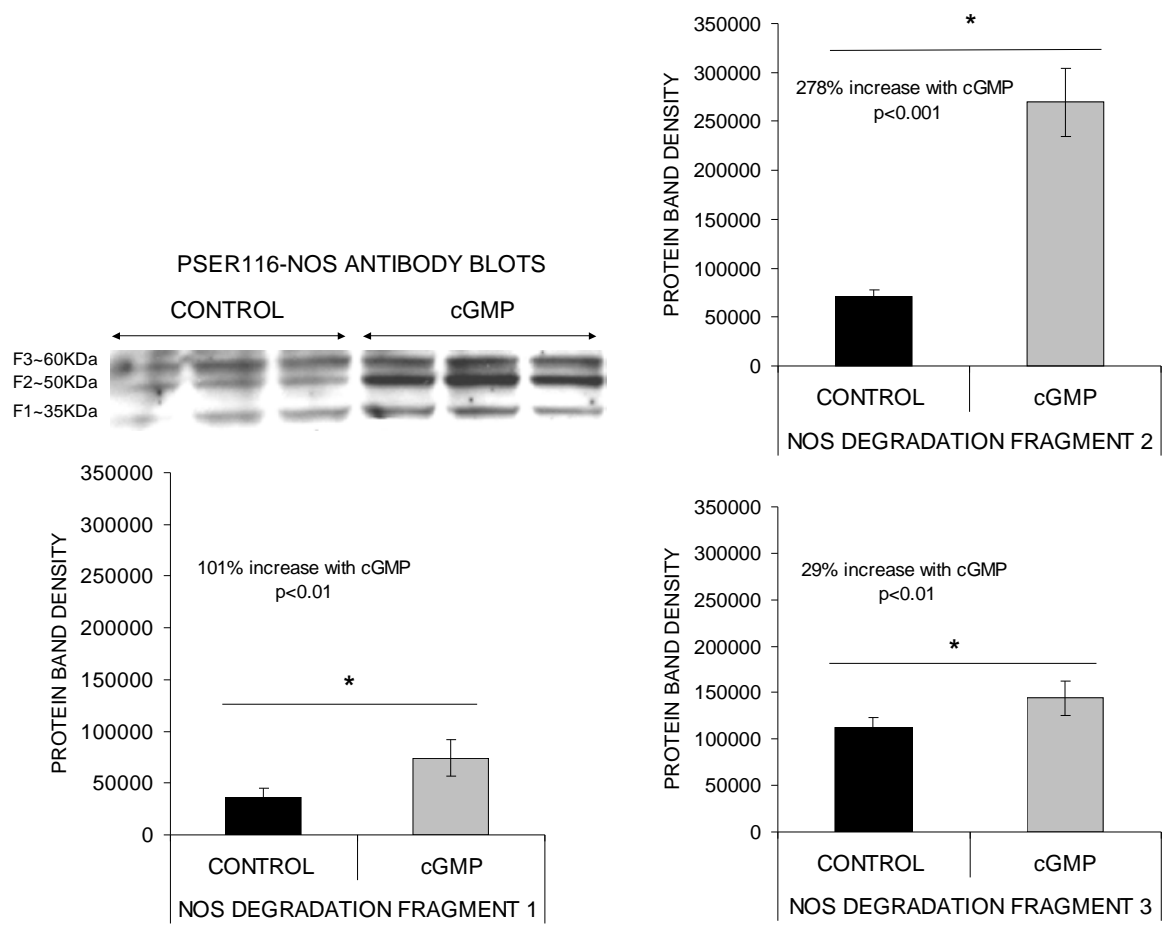

Fig. 15.40 PKG activation increases anti-serine116-NOS antibody labeling of NOS N-terminal fractions in normal endothelial cells. LMVECs from a single suspension were equally seeded in 100mm diameter dishes. Five-day-confluent triplicate monolayers were used for controls and identical triplicate monolayers of sibling cells were used as tests treated with $300 \mathrm{nM}$ 8Br-cGMP (Calbiochem, CA) for 15 min before routine immunoblot analysis. After electrophoresis and transfer of proteins to a membrane, the membrane was blocked with $5 \%$ non-fat milk and then incubated with a primary antibody against phosphorylated serine-116 region of NOS (1: 200 concentration, Sigma, St. Louis) at 4C for $24 \mathrm{~h}$ with gentle rocking. Protein bands were visualized by horseradish peroxidase conjugated secondary antibodies (Amersham, Buckinghamshire, UK) using Super Signal® West Pico Chemiluminescent Substrate kit (Pierce, Rockford, IL) to prepare the developing solution. Membranes were exposed to Blue Lite Autorad Films (ISC BioExpress, Kaysville, UT), and the films were processed in a HOPE developer. The film developed from western blotting showed that serine-116 phosphorylated NOS can be normally found in control cells as enzyme fragments and that these fragments are increased by PKG activation. 

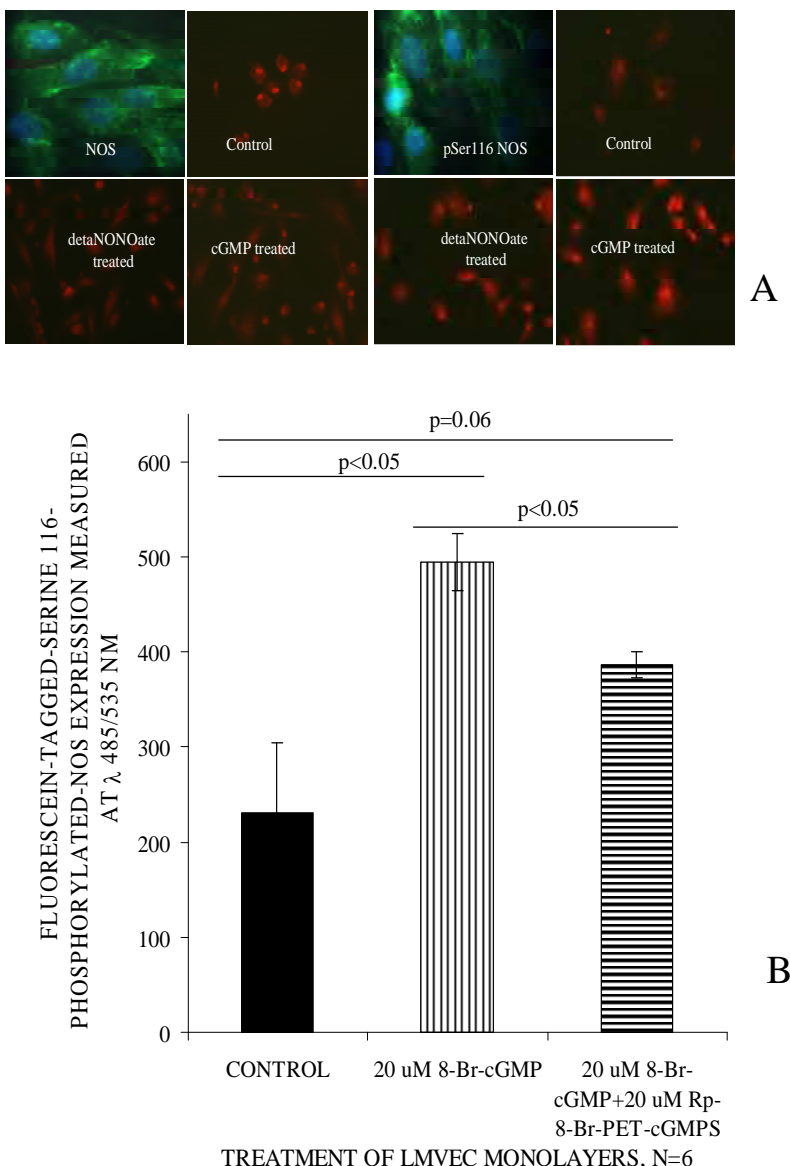

B

Fig. 16.32 Protein kinase G (PKG) activation decreases immunofluorescence of nitric oxide synthase (NOS) and increases that of the serine 116 phosphorylated analogue, pSer116-NOS, in lung microvascular endothelial cells (LMVECs). A: The PKG-modulating drugs were incubated with cells $30 \mathrm{~min}$ before fixation. Cells were processed using routine fluorescence immunohistochemistry with specific primary antibodies and species corresponding secondary antibodies. Left upper panels show that eNOS in control cells is found in the plasmalemma and cytosol as green Alexa 488-tagged NOS and also in the nucleus as red cy3-tagged NOS; the lower panels show that both 170 micromol/L diethylenetriamine NONOate (DETANONOate) and 3 micromol/L 8-Br-cGMP decrease NOS-cy3 expression. Right upper panels show that pSer116-NOS in control cells is found in the cytosol as green Alexa 488-tagged pSer116-NOS and also in the nucleus as red cy3-tagged NOS; the lower panels show that both 170 micromol/L DETANONOate and 3 micromol/L 8-Br-cGMP increased pSer116-NOS-cy3 expression in the cytosol and nucleus. Figures are representative of two experiments. B: The graph shows quantitative modification of serine 116 immunofluorescence by 8-Br-cGMP. Stably confluent monolayers of LMVEC $(n=3)$ were treated with the PKG activator 20 micro mol/L 8-Br-cGMP with/without 20 
micromol/L PKG inhibitor Rp-phenyl-1,N2-etheno-8-bromoguanosine-3', 5' -cyclic monophosphorothionate (Rp-8-bromo-PET-cGMPS) 10 min before fixation with $4 \%$ paraformaldehyde. The inhibitors were given $1 \mathrm{~h}$ before the activator. Fluorescence immunohistochemistry was performed with fluorescein-tagged secondary antibody. The fluorescence was read with a Victor 1420 multilabel counter (Perkin-Elmer, Waltham, MA, USA) with a fluorescein setting ( $\lambda$ ex/em $485 / 535 \mathrm{~nm}$ ). Fluorescence intensity was increased by 8 -Br-cGMP $(\mathrm{p}<0.05)$ and the effect was attenuated by Rp-8-Br-PET-cGMPS $(\mathrm{p}<0.05)$. The figure is a representative of two experiments.

A

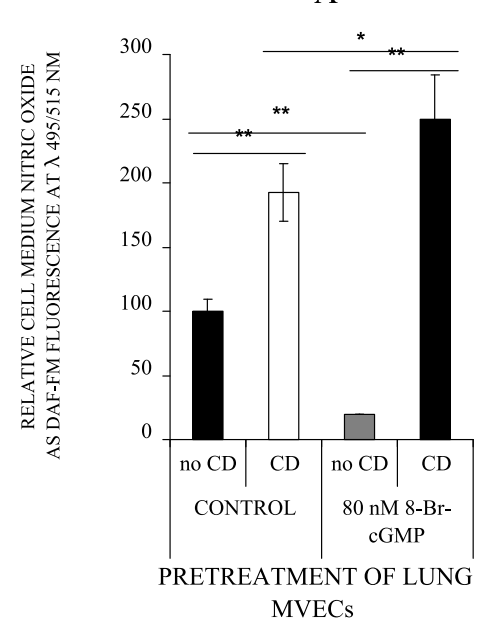

B

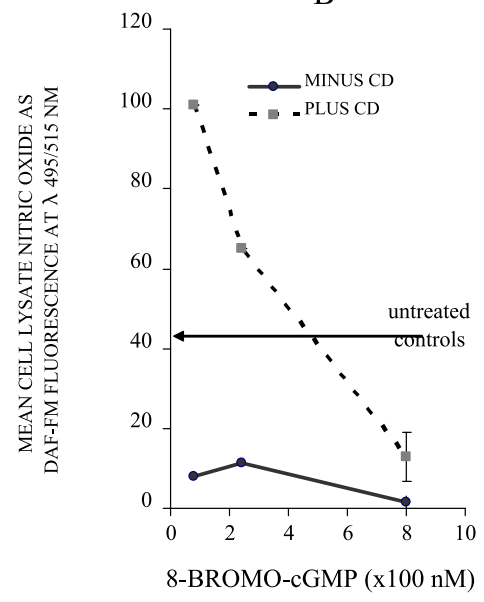

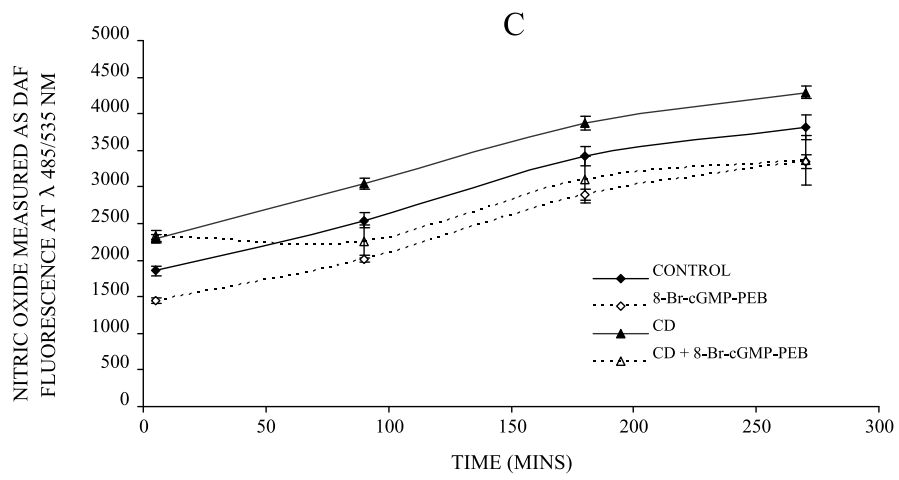

Fig. 17.32 Lipid vesicles are involved in protein kinase G (PKG) interaction with nitric oxide synthase (NOS). Confluent monolayers were treated with cholesterol extractor 2 micromol/L cyclodextrin (CD) for $2 \mathrm{~h}$ to disrupt lipid vesicles and then incubated with various concentrations of 8 -Br-cGMP and a combination of 0.5 micromol/L DAF-FM and cell-permeable 0.8 micromol/L DAF-FM diacetate, plus 4 microg/ $\mathrm{mL}$ calcium ionophore to stimulate nitric oxide $(\mathrm{NO})$ production. Nitric oxide produced was measured after $15 \mathrm{~min}$ of 
incubation with DAF. Control cells were similarly treated with the exclusion of only CD. (A) Cell medium NO measurements from cells treated with CD showed greater NO production. In the absence of $\mathrm{CD}, 8$-Br-cGMP caused a decrease in NO production. Cells with disrupted lipid lacked 8-Br-cGMP-inhibition of NOS. (B) Cell lysate NO measurements increased for various concentrations of 8 -Br-cGMP in cells treated with $\mathrm{CD}$ compared with cells not treated with $C D$. Lipid disruption with $C D$ raised NO production significantly $(p<0.01$ for each 8-Br-cGMP concentration; $n=6$ ). The effect of lipid disruption diminished with increasing concentrations of 8-Br-cGMP. (C) Time-course of the effect of CD on basal NO production. Cells were used in groups of 12 wells each for various controls and tests. All test groups were pretreated before adding DAF with $100 \mathrm{mmol} / \mathrm{L}$ PKG activator guanosine-3'5 -cyclic monophosphonate- $\beta$-phenyl-1NF-ethano-8-Br Na salt (8-Br-cGMP-PEB; $10 \mathrm{~min}$ before) without or with $20 \mathrm{mmol} / \mathrm{L} \mathrm{CD}$ (given $2 \mathrm{~h}$ before) or with $\mathrm{CD}$ alone. Controls were included. Using paired t-tests, the differences at the 270 min time-point between both the controls and 8-Br-cGMP-PEB groups and the controls and CD groups were significant at $\mathrm{p}<$ 0.05 .

\section{Hypothetical comparison of the negative regulatory roles of caveolin-1 and PKG on endothelial NOS - a review of literature.}

Figure 18 and Table 1 compare the role of the well-studied caveolin- 1 and the emerging role of PKG in inhibiting NOS. Both are endogenous components of cellular function under physiologic conditions. Caveolin- 1 has been known as a negative regulator of NOS for many years but there is lack of significant clinical usage derived from this in terms of drug and molecular targeting and endogenous NO regulation. The suggested feedback role of PKG in the NOS metabolic cycle needs further studies for possible clinical applications. One aspect may be to target the $\mathrm{N}$-terminal moiety (serine 116 region) that might be involve in transcription and de novo synthesis of NOS enzyme. This may be manipulated for utilization in vascular, neuronal, and other functional disorders involving NO.

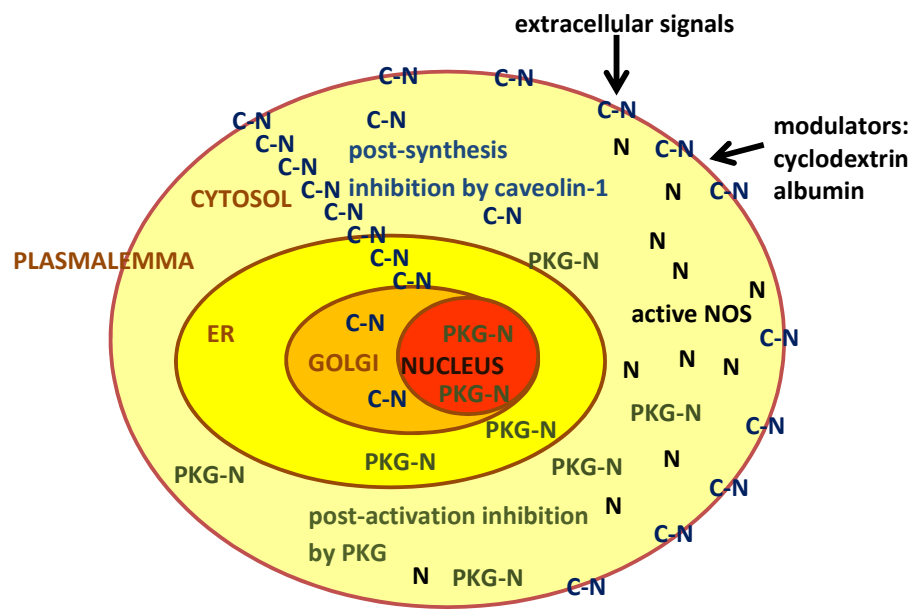

Fig. 18. Hypothetical schema of differential subcellular co-localization of caveolin-1 or PKG1beta as inhibitors of NOS in endothelial cells. Caveolin-1 co-localizes with and is 
known to inhibit nascent NOS produced in the Golgi or supplied to the plasma membrane for extracellular signals. The figure depicts caveolin-1 bound to NOS in the Golgi network and plasmalemma as Figure 13 indicates and as previous workers have shown. $67,68,69,62,63,64$ The figure also depicts that PKG inhibits NOS after it is activated in the cytosol and is involved in the recycling of spent NOS as Figure 2 indicates. By some mechanism PKG colocalizes with NOS or with a NOS fragment in the nuclear region. Key: $\mathrm{N}=$ free nitric oxide synthase; C-N = hypothetical caveolin-1-NOS complex; PKG-N = hypothetical protein kinase G-NOS complex.

\begin{tabular}{|c|c|c|}
\hline COMPARISON & CAVEOLIN-1 & PKG \\
\hline Molecular effect on NOS & $\begin{array}{l}\text { post-translational } \\
\text { inhibition } 62,63,52\end{array}$ & post activity inhibition 32,38 \\
\hline $\begin{array}{l}\text { Speculation on the form } \\
\text { of NOS affected }\end{array}$ & $\begin{array}{l}\text { nascent (membrane bound) } \\
\text { NOS } 64,65,66\end{array}$ & $\begin{array}{l}\text { active NOS after NO production, or } \\
\text { spent NOS } 39,40,41\end{array}$ \\
\hline $\begin{array}{l}\text { Subcellular co- } \\
\text { localization with NOS }\end{array}$ & $\begin{array}{l}\text { plasma membrane, } \\
\text { caveolae, golgi } 50,67,68,69\end{array}$ & $\begin{array}{l}\text { Cytosol, nucleus, endoplasmic } \\
\text { reticulum } 32,41\end{array}$ \\
\hline Biological result & $\begin{array}{l}\text { makes NOS available for } \\
\text { extracellular signals } 49,52,56 \text {, } \\
43,68\end{array}$ & $\begin{array}{l}\text { pro-translocation phosphorylation for } \\
\text { enzyme degradation and recycling } \\
40,41\end{array}$ \\
\hline Activators & $\begin{array}{l}\text { calcium-calmodulin } 53,68,70, \\
71 \\
\text { albuminin }^{72,73} \\
\text { membrane lipid }_{\text {disruption }}^{72,32} \\
\text { bradykinin, acetyl choline } \\
\text { b6 }\end{array}$ & cGMP analogues 38,39 \\
\hline Effect of activators & increased NO production 72 & decreased NO production $32,38,39$ \\
\hline Inhibitors & hypoxia 72,74 & cGMP analogues 38,39 \\
\hline Effect of inhibitors & decreased NO production $^{72}$ & increased NO production $^{38,39}$ \\
\hline
\end{tabular}

Table 1. Comparison of the negative regulatory roles of constitutive caveolin- 1 and constitutive PKG on nitric oxide synthase in the endothelium.

Protein Kinase G inhibits activated NOS by a feedback mechanism. Its actions appear to involve phosphorylation changes as well as molecular changes on the NOS molecule (Figure 19) that determine the fate of the spent enzyme. The spent enzyme, from pictorial indications, appears to enter a vesicular system possibly as a degraded $\mathrm{N}$-terminal form. The role of this cycle and the therapeutic possibilities linked to it are yet to be expanded. 


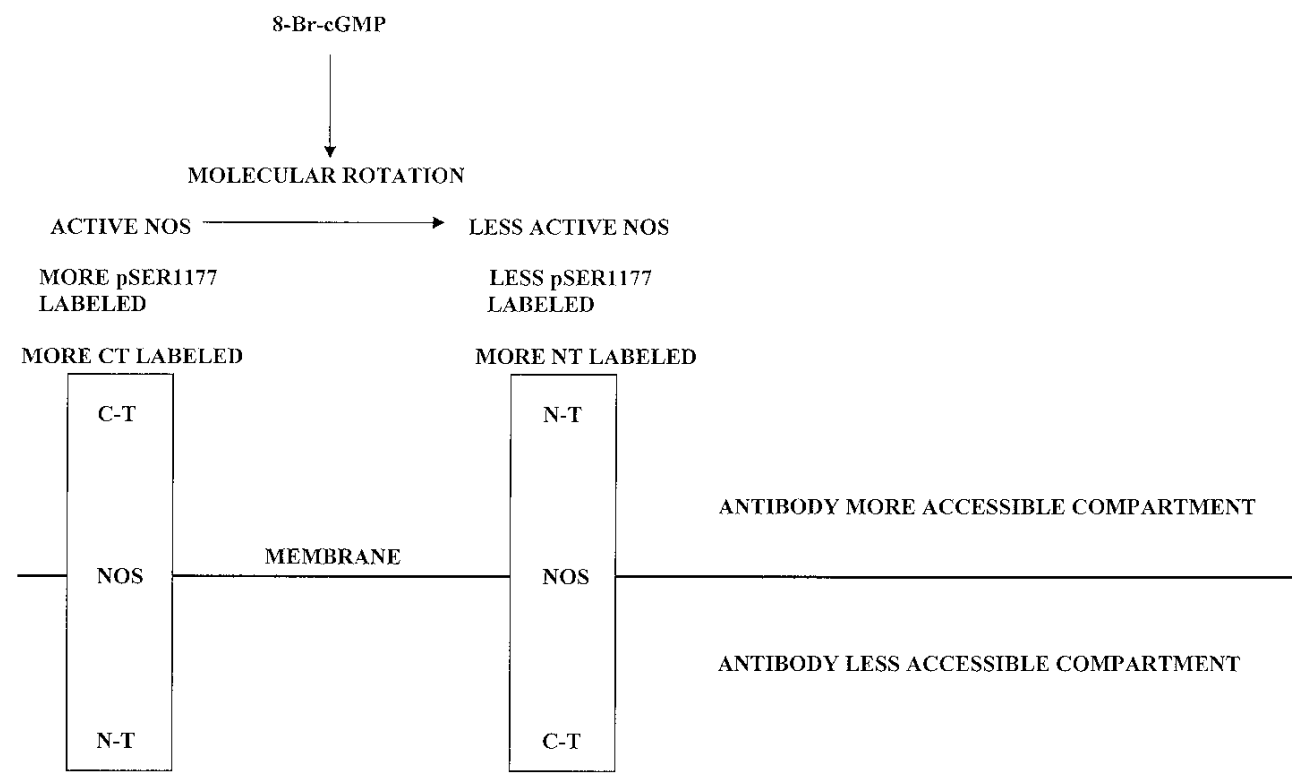

Fig. 19. A hypothetical depiction of molecular and phosphorylation effects of PKG on NOS.

\section{Conclusions}

- $\quad$ Protein kinase $\mathrm{G}$ isoforms are normally found in endothelial cells

- NO signaling activates guanylate cyclase and leads to activation of PKG in endothelial cells

- $\quad$ PKG activation via NO-GC-cGMP signaling in endothelial cells appears to exert a feedback on active NOS.

- $\quad$ Serine116-phosphorylated NOS appears to be spent NOS and to be chaperoned with PKG 1 beta

- $\quad$ Serine116-phosphorylated NOS moiety enters a vesicular system including the nucleus.

- Serine116-phosphorylated NOS moiety may be an important messenger for replenishing the cell with nascent NOS enzyme.

\section{Acknowledgements}

The data presented here were taken from five papers published by the following journals: Clinical and Experimental Pharmacology and Physiology; The Anatomical Record; African 
Journal of Medicine and Medical Sciences; Nigerian Journal of Physiology; and African Health Sciences. The authors appreciate their permissions for using the published data. Most of the work reported here on protein kinase $\mathrm{G}$ was done at the Los Angeles Biomedical Research Institute at Harbor UCLA Medical Center (LABiomed), Torrance, California. Grant funding and resources were provided by the laboratory of Prof. J. Usha Raj at the Division of Neonatology, Department of Pediatrics, LABiomed, Torrance, California, USA. The publication of the present Chapter was sponsored by Lagos State University College of Medicine, Lagos, Nigeria.

\section{References}

[1] Furchgott RF, Vanhoutte PM. Endothelium-derived relaxing and contracting factors. FASEB J 1989; Jul;3(9):2007-18.

[2] Palmer RM, Ferrige AG, Moncada S. Nitric oxide release accounts for the biological activity of endothelium-derived relaxing factor. Nature 1987; Jun 1117;327(6122):524-6.

[3] Ignarro LJ, Buga GM, Wood KS, Byrns RE, Chaudhuri G. Endothelium-derived relaxing factor produced and released from artery and vein is nitric oxide. Proc Natl Acad Sci USA 1987; Dec;84(24):9265-9.

[4] Furchgott RF, Jothianandan D. Endothelium-Dependent and -Independent Vasodilation Involving Cyclic GMP: Relaxation Induced by Nitric Oxide, Carbon Monoxide and Light. Blood Vessels 1991;28:52-61 (Now J Vascular Research).

[5] Arnal JF, Dinh-Xuan AT, Pueyo M, Darblade B, Rami J. Endothelium-derived nitric oxide and vascular physiology and pathology. Cell Mol Life Sci 1999; 55(8-9):107887. Review.

[6] Hobbs AJ, Higgs A, Moncada S. Inhibition of nitric oxide synthase as a potential therapeutic target. Anna. Rev. Pharmacol. Tooxicol, 1999, 39:1337-1356.

[7] Moncada S, Palmer RM, Higgs EA. Biosynthesis of nitric oxide from L-arginine. A pathway for the regulation of cell function and communication. Biochem Pharmacol. 1989 Jun 1;38(11):1709-15.

[8] Vanhoutte PM. Endothelium and control of vascular function. State of the Art lecture. Hypertension. 1989 Jun;13(6 Pt 2):658-67. Review.

[9] Michel T, Feron O. Nitric oxide synthases. Which, where, how, and why? J. Clin. Invest. 1997; 100: 2146-52.

[10] Radomski MW, Palmer RM, Moncada S. An L-arginine/nitric oxide pathway present in human platelets regulates aggregation. Proc Natl Acad Sci U S A. 1990 Jul;87(13):5193-7.

[11] Moncada S, Higgs A. The L-arginine-nitric oxide pathway. N Engl J Med. 1993 Dec 30;329(27):2002-12.

[12] Garthwaite J. Glutamate, nitric oxide and cell-cell signalling in the nervous system. Trends Neurosci. 1991 Feb;14(2):60-7. Review

[13] Snyder SH, Bredt DS. Biological roles of nitric oxide. Sci Am. 1992 May;266(5):68-71, 747. 
[14] Gillespie JS, Liu XR, Martin W. The effects of L-arginine and NG-monomethyl Larginine on the response of the rat anococcygeus muscle to NANC nerve stimulation. Br J Pharmacol. 1989 Dec;98(4):1080-2.

[15] Rand MJ. Nitrergic transmission: nitric oxide as a mediator of non-adrenergic, noncholinergic neuro-effector transmission. Clin Exp Pharmacol Physiol. 1992 Mar;19(3):147-69. Review

[16] Toda N. Regulation of blood pressure by nitroxidergic nerve. J Diabetes Complications. 1995 Oct-Dec;9(4):200-2. Review

[17] Arnold WP, Mittal CK, Katsuki S, Murad F. Nitric oxide activates guanylate cyclase and increases guanosine 3':5'-cyclic monophosphate levels in various tissue preparations. Proc Natl Acad Sci U S A. 1977 Aug;74(8):3203-7.

[18] Ignarro LJ. Heme-dependent activation of guanylate cyclase by nitric oxide: a novel signal transduction mechanism. Blood Vessels. 1991;28(1-3):67-73. Review

[19] Gruetter CA, Barry BK, McNamara DB, Gruetter DY, Kadowitz PJ, Ignarro L. Relaxation of bovine coronary artery and activation of coronary arterial guanylate cyclase by nitric oxide, nitroprusside and a carcinogenic nitrosoamine. J Cyclic Nucleotide Res. 1979;5(3):211-24.

[20] Murad F. The nitric oxide-cyclic GMP signal transduction system for intracellular and intercellular communication. Recent Prog Horm Res. 1994;49:239-48. Review.

[21] Gao Y, Dhanakoti S, Tolsa J-F and Raj JU. Role of protein kinse G in nitric oxide- and cGMP-induced relaxation of newborn ovine pulmonary veins. J App physiol 1999; 87: 993-998.

[22] Surks HK, Mochizuki N, Kasai Y, Georgescu SP, Tang KM, Ito M, Lincoln TM, Mendelsohn ME. Regulation of myosin phosphatase by a specific interaction with cGMP- dependent protein kinase Ialpha. Science. 1999 Nov 19;286(5444):1583-7.

[23] Marletta MA, Yoon PS, Iyengar R, Leaf CD, Wishnok JS. Macrophage oxidation of Larginine to nitrite and nitrate: nitric oxide is an intermediate. Biochemistry. 1988 Nov 29;27(24):8706-11.

[24] Hibbs JB Jr, Taintor RR, Vavrin Z, Rachlin EM. Nitric oxide: a cytotoxic activated macrophage effector molecule. Biochem Biophys Res Commun. 1988 Nov 30;157(1):87-94. Erratum in: Biochem Biophys Res Commun 1989 Jan 31;158(2):624.

[25] Stuehr DJ, Nathan CF. Nitric oxide. A macrophage product responsible for cytostasis and respiratory inhibition in tumor target cells. J Exp Med. 1989 May 1;169(5):154355.

[26] Nussler AK, Billiar TR. Inflammation, immunoregulation, and inducible nitric oxide synthase. J Leukoc Biol. 1993 Aug;54(2):171-8. Review.

[27] Nathan C. The moving frontier in nitric oxide-dependent signaling. Sci STKE. 2004 Nov 2;2004(257):pe52. Review.

[28] Isenović E, Soskić S, Düngen HD, Dobutovic B, Elvis T, Simone I, Marche P. Regulation of endothelial nitric oxide synthase in pathophysiological conditions. Cardiovasc Hematol Disord Drug Targets. 2011 Oct 26. [Epub ahead of print]

[29] Ignarro LJ, Napoli C. Novel features of nitric oxide, endothelial nitric oxide synthase, and atherosclerosis. Curr Diab Rep. 2005 Feb;5(1):17-23. Review. 
[30] Hwang SJ, Lee KH, Hwang JH, Choi CW, Shim JW, Chang YS, Park WS. Factors affecting the response to inhaled nitric oxide therapy in persistent pulmonary hypertension of the newborn infants. Yonsei Med J. 2004 Feb 29;45(1):49-55

[31] Mourani PM, Ivy DD, Gao D, Abman SH. Pulmonary vascular effects of inhaled nitric oxide and oxygen tension in bronchopulmonary dysplasia. Am J Respir Crit Care Med. 2004 Nov 1;170(9):1006-13. Epub 2004 Jun 7.

[32] John TA, Ibe BO, Raj JU. Regulation of endothelial nitric oxide synthase in neonatal lamb lung microvascular endothelial cells: role of protein kinase G, lipid structures and serine 116 phosphorylation. Clinical and Experimental Pharmacology and Physiology 2008; Feb;35(2):148-58. Epub Sep 242007.

[33] Brovkovych V, Stolarczyk E, Oman J, Tomboulian P, Malinski T. Direct electrochemical measurement of nitric oxide in vascular endothelium. J Pharmaceutical and Biochemical Analysis 1999; 19: 135-143.

[34] Kojima H, Sakurai K, Kikuchi K, Kawahara S, Kirino Y, Nagoshi H, Hirata Y, Nagano T. Development of a fluorescent indicator for nitric oxide based on the fluorescein chromophore. Chem Pharm Bull (Tokyo). 1998 Feb; 46(2): 373-5.

[35] Rathel TR, Leikert JF, Vollmar AM, Dirsch VM. Application of 4,5-diaminofluorescein to reliably measure nitric oxide released from endothelial cells in vitro. Biol Proced Online. 2003; 5: 136-142. Epub 2003 Jun 15.

[36] Leikert JF, Rathel TR, Muller C, Vollmar AM, Dirsch VM. Reliable in vitro measurement of nitric oxide released from endothelial cells using low concentrations of the fluorescent probe 4,5-diaminofluorescein. FEBS Lett. 2001 Oct 5; 506(2): 131-4.

[37] Lopez-Figueroa MO, Caamano C, Marin R, Guerra B, Alonso R, Morano MI, Akil H, Watson SJ. Characterization of basal nitric oxide production in living cells. Biochim Biophys Acta. 2001 Sep 26; 1540(3): 253-64.

[38] John TA. Protein kinase G inhibits basal and stimulated nitric oxide synthase activity in neonatal ovine lung microvascular endothelial cells. Af J Med med Sci 2010; 39: 8998.

[39] John TA, Raj JU. A fluorescence activated cell sorter analysis of the relationship between protein kinase G and endothelial nitric oxide synthase. Anatomical Record 2010; 293(10): 1755-1765.

[40] John TA. Protein kinase G may exert pro-degradation inhibition on nitric oxide synthase. Nigerian Journal of Physiological Sciences 2011; 26(1): 1-6.

[41] John TA, Raj JU. Inhibitors caveolin-1 and protein kinase G show differential subcellular colocalization with nitric oxide synthase. Af Health Sc. 11(4): 526-534.

[42] Mount PF, Kemp BE, Power DA. Regulation of endothelial and myocardial NO synthesis by multi-site eNOS phosphorylation. J Mol Cell Cardiol. 2007 Feb;42(2):271-9. Epub 2006 Jul 12. Review

[43] Fleming I, Busse R. Molecular mechanisms involved in the regulation of the endothelial nitric oxide synthase. Am J Physiol Regul Integr Comp Physiol. 2003 Jan;284(1):R112. Review.

[44] Gratton JP, Fontana J, O'Connor DS, Garcia-Cardena G, McCabe TJ, Sessa WC. Reconstitution of an endothelial nitric-oxide synthase (eNOS), hsp90, and caveolin- 
1 complex in vitro. Evidence that hsp90 facilitates calmodulin stimulated displacement of eNOS from caveolin-1. J Biol Chem 2000; 275: 22268-22272.

[45] Schilling K, Opitz N, Wiesenthal A, Oess S, Tikkanen R, Muller-Esterl W, Icking A. Translocation of endothelial nitric-oxide synthase involves a ternary complex with caveolin-1 and NOSTRIN. Mol Biol Cell. 2006 Sep; 17(9):3870-80. Epub 2006 Jun 28.

[46] Schleicher M, Brundin F, Gross S, Muller-Esterl W, Oess S. Cell cycle-regulated inactivation of endothelial NO synthase through NOSIP-dependent targeting to the cytoskeleton. Mol Cell Biol. 2005 Sep; 25(18):8251-8.

[47] Boo YC, Sorescu G, Boyd N, Shiojima I, Walsh K, Du J, Jo H. Shear stress stimulates phosphorylation of endothelial nitric-oxide synthase at Ser1179 by Aktindependent mechanisms: role of protein kinase A. J Biol Chem. 2002 Feb 1;277(5):3388-96. Epub 2001 Nov 29.

[48] Leikert JF, Räthel TR, Wohlfart P, Cheynier V, Vollmar AM, Dirsch VM. Red wine polyphenols enhance endothelial nitric oxide synthase expression and subsequent nitric oxide release from endothelial cells. Circulation. 2002 Sep 24;106(13):1614-7.

[49] García-Cardeña G, Oh P, Liu J, Schnitzer JE, Sessa WC. Targeting of nitric oxide synthase to endothelial cell caveolae via palmitoylation: implications for nitric oxide signaling. Proc Natl Acad Sci USA 1996; 25;93(13): 6448-53.

[50] Shaul PW, Smart EJ, Robinson LJ, German Z, Yuhanna IS, Ying Y, Anderson RG, Michel T. Acylation targets emdothelial nitric-oxide synthase to plasmalemmal caveolae. J Biol Chem 1996; 271(11):6518-22.

[51] Ju H, Venema VJ, Marrero MB, Venema RC. Inhibitory interactions of the bradykinin B2 receptor with endothelial nitric-oxide synthase. J Biol Chem 1998; 273(37): 2402524029.

[52] Feron O, Saldana F, Michel J B, Michel T. The endothelial nitric-oxide synthase-caveolin regulatory cycle. J Biol Chem 1998; 273: 3125-3128.

[53] Bredt DS, Ferris CD, Snyder SH. Nitric oxide synthase regulatory sites. Phosphorylation by cyclic AMP-dependent protein kinase, protein kinase C, and calcium/calmodulin protein kinase; identification of flavin and calmodulin binding sites. J Biol Chem. 1992 Jun 5;267(16):10976-81.

[54] Dedio J, Konig P, Wohlfart P, Schroeder C, Kummer W, Muller-Esterl W. NOSIP, a novel modulator of endothelial nitric oxide synthase activity. FASEB J 2001; 15: 7989.

[55] Zimmermann K, Opitz N, Dedio J, Renne C, Muller-Esterl W, Oess S. NOSTRIN: a protein modulating nitric oxide release and subcellular distribution of endothelial nitric oxide synthase. Proc Natl Acad Sci USA 2002; 99: 17167-17172.

[56] Fulton D, Gratton J-P, Sessa WC. Post-translation control of endothelial nitric oxide synthase: why isn't calcium/calmodulin enough? JPET 2001; 299(3): 818-824.

[57] Fleming I, Busse R. Signal transduction of eNOS activation. Cardiovascular Res.1999 Aug 15; 43(3): 532-541.

[58] Rafikov R, Fonseca FV, Kumar S, Pardo D, Darragh C, Elms S, Fulton D, Black SM. eNOS activation and NO function: structural motifs responsible for the posttranslational control of endothelial nitric oxide synthase activity. J Endocrinol. 2011 Sep;210(3):271-84. Epub 2011 Jun 3. Review 
[59] Rothberg KG, Heuser JE, Donzell WC, Ying Y-S, Glenney JR, Anderson RGW. Caveolin, a protein component of caveolae membrane coats. Cell 1992; 68:673-682.

[60] Das K, Lewis RY, Scherer PE, Lisanti MP. The membrane-spanning domains of caveolins-1 and -2 mediate the formation of caveolin hetero-oligomers. Implications for the assembly of caveolae membranes in vivo. J Biol Chem 1999; 274:18721-18728.

[61] Oess S, Icking A, Fulton D, Govers R, Müller-Esterl W. Subcellular targeting and trafficking of nitric oxide synthases. Biochem J. 2006 Jun 15;396(3):401-9. Review

[62] Garcia-Cardena G, Fan R, Stern DF, Liu J, Sessa WC. Endothelial nitric oxide synthase is regulated by tyrosine phosphorylation and interacts with caveolin-1. J Biol Chem 1996; 271(44):27237-40.

[63] Ju H, Zou R, Venema VJ, Venema RC. Direct interaction of endothelial nitric-oxide synthase and caveolin-1 inhibits synthase activity. J Biol Chem 1997; 272(30):185225.

[64] Feron O, Michel JB, Sase K, Michel T. Dynamic regulation of endothelial nitric oxide synthase: complementary roles of dual acylation and caveolin interactions. Biochemistry 1998; 37(1):193-200.

[65] Michel T. Targeting and translocation of endothelial nitric oxide synthase. Braz J Med Biol Res. 1999 Nov;32(11):1361-6. Review

[66] Prabhakar P, Thatte HS, Goetz RM, Cho MR, Golan DE, Michel T. Receptor-regulated translocation of endothelial nitric-oxide synthase. J Biol Chem 1998; 273(42): 273838.

[67] O'Brien AJ, Young HM, Povey JM, Furness JB. Nitric oxide synthase is localized predominantly in the Golgi apparatus and cytoplasmic vesicles of vascular endothelial cells. Histochem Cell Biol. 1995 Mar;103(3):221-5

[68] Fulton D, Babbitt R, Zoellner S, Fontana J, Acevedo L, McCabe TJ, Iwakiri Y, Sessa WC.Targeting of endothelial nitric-oxide synthase to the cytoplasmic face of the Golgi complex or plasma membrane regulates Akt- versus calcium-dependent mechanisms for nitric oxide release. J Biol Chem. 2004 Jul 16;279(29):30349-57. Epub 2004 May 10

[69] Zhang Q, Church JE, Jagnandan D, Catravas JD, Sessa WC, Fulton D. Functional relevance of Golgi- and plasma membrane-localized endothelial NO synthase in reconstituted endothelial cells. Arterioscler Thromb Vasc Biol 2006; 26(5):101521.Epub 2006 Mar 2.

[70] Michel JB, Feron O, Sacks D, Michel T. Reciprocal regulation of endothelial nitric-oxide synthase by $\mathrm{Ca}^{2+}$-calmodulin and caveolin. J Biol Chem 1997; 272(25):15583-6.

[71] Forstermann U, Pollock JS, Schmidt HH, Heller M, Murad F. Calmodulin-dependent endothelium-derived relaxing factor/nitric oxide synthase activity is present in the particulate and cytosolic fractions of bovine aortic endothelial cells. Proc Natl Acad Sci USA 1991; 88: 1788-1792.

[72] John TA, Ibe BO, Raj JU. Oxygen alters caveolin-1 and nitric oxide synthase-3 functions in ovine fetal and neonatal lung microvascular endothelial cells. Am J Physiol Lung Cell Mol Physiol 2006; 291(5): L1079-93. 
[73] Maniatis NA, Brovkovych V, Allen SE, John TA, Shajahan AN, Tiruppathi C, Vogel SM, Skidgel RA, Malik AB, Minshall RD. Novel mechanism of endothelial nitric oxide synthase activation mediated by caveolae internalization in endothelial cells. Circ Res. 2006 Oct 13;99(8):870-7. Epub 2006 Sep 14.

[74] Murata T, Sato K, Hori M, Ozaki H, Karaki H. Decreased endothelial nitric-oxide synthase (eNOS) activity resulting from abnormal interaction between eNOS and its regulatory proteins in hypoxia-induced pulmonary hypertension. J Biol Chem. 2002 Nov 15;277(46):44085-92. Epub 2002 Aug 15. 


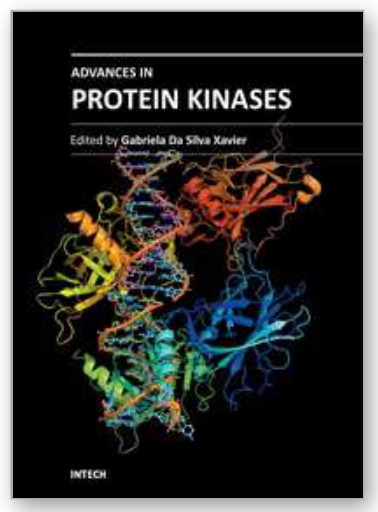

\author{
Advances in Protein Kinases \\ Edited by Dr. Gabriela Da Silva Xavier
}

ISBN 978-953-51-0633-3

Hard cover, 374 pages

Publisher InTech

Published online 05, June, 2012

Published in print edition June, 2012

Proteins are the work horses of the cell. As regulators of protein function, protein kinases are involved in the control of cellular functions via intricate signalling pathways, allowing for fine tuning of physiological functions. This book is a collaborative effort, with contribution from experts in their respective fields, reflecting the spirit of collaboration - across disciplines and borders - that exists in modern science. Here, we review the existing literature and, on occasions, provide novel data on the function of protein kinases in various systems. We also discuss the implications of these findings in the context of disease, treatment, and drug development.

\title{
How to reference
}

In order to correctly reference this scholarly work, feel free to copy and paste the following:

Theresa A. John and J. Usha Raj (2012). The Physiological Relationship of Endothelial Protein Kinase G with Endothelial Nitric Oxide Synthase, Advances in Protein Kinases, Dr. Gabriela Da Silva Xavier (Ed.), ISBN: 978953-51-0633-3, InTech, Available from: http://www.intechopen.com/books/advances-in-protein-kinases/thephysiological-relationship-of-endothelial-protein-kinase-g-with-endothelial-nitric-oxide-syn

\section{INTECH}

open science | open minds

\section{InTech Europe}

University Campus STeP Ri

Slavka Krautzeka 83/A

51000 Rijeka, Croatia

Phone: +385 (51) 770447

Fax: +385 (51) 686166

www.intechopen.com

\section{InTech China}

Unit 405, Office Block, Hotel Equatorial Shanghai

No.65, Yan An Road (West), Shanghai, 200040, China

中国上海市延安西路65号上海国际贵都大饭店办公楼 405 单元

Phone: +86-21-62489820

Fax: +86-21-62489821 
(C) 2012 The Author(s). Licensee IntechOpen. This is an open access article distributed under the terms of the Creative Commons Attribution 3.0 License, which permits unrestricted use, distribution, and reproduction in any medium, provided the original work is properly cited. 